\title{
THE DYNAMICS OF GROWTH POLICY FORMULATION AND IMPLEMENTATION: A MASSACHUSETTS CASE STUDY*
}

\author{
LaWREnce Susskind $\dagger$ \\ Charles Perry $\ddagger$ \\ I \\ BACKGROUND
}

The enactment of state land use legislation in the early 1970s was marked by a sense of imminent crisis. ${ }^{1}$ Dramatic incidents of environmental damage, rapid urbanization, and a fear of detrimental land use changes led Vermont, Maine, Florida, California, Oregon and a number of other states to adopt laws superseding local control over growth management and land use decisions. ${ }^{2}$ State land use planning and growth management statutes generally have called for state supervision of local decisions through plan guidelines or regional review of specific development proposals, state review of the location of major facilities such as airports or power plants, and supervision of development in wetlands, coastal areas, or historic sites. ${ }^{3}$ Recently, support for extensive state intervention into land use decision making has begun to ebb. Several states that enacted legislation are now finding it difficult to implement

\footnotetext{
* This paper is based on three technical reports: Charles Perry and Lawrence Susskind, "The Massachusetts Growth Policy Development Act: Intent and Passage" (Department of Urban Studies and Planning, Massachusetts Institute of Technology, April I, 1977); Lawrence Susskind and Michael Elliott, "A Survey of Local Growth Policy Committees and Their Impacts" (Department of Urban Studies and Planning, Massachusetts Institute of Technology, July, 1977); and Lawrence Susskind and Charles Perry, "The Impact of Local Participation on the Formulation of State Growth Policy in Massachusetts", (Department of Urban Studies and Planning, Massachusetts Institute of Technology, October, 1977). This research was undertaken as part of the Massachusetts Growth Policy Project supported by a grant from the Natural and Environmental Systems Division of the Rockefeller Foundation. The opinions expressed in this paper are those of the authors and do not necessaarily reflect the views of the Rockefeller Foundation or The Massachusetts Institute of Technology.

$\dagger$ Associate Professor and Head, Department of Urban Studies and Planning, Massachusetts Institute of Technology.

†† Doctoral Candidate, Department of Urban Studies and Planning, Massachusetts Institute of Technology.

1. See R. Healy, land Use and the States (1976); R. Linowes \& D. Allenworth, The States and Land Use Control. (1975); D. Mandelker, Environmental and Land Controls LEGISLATION (1976).

2. For an analysis of the pattern of state adoption of land use controls, see N. RosenBAum, Land USE ANd the Legislatures (1976).

3. D. Mazmanian \& P. Sabatier, Analysis of the Implementation of Land Use Policy: Project Summary, N.S.F. Grant ENV 77-14589 (July 1977), at 1 .
} 
the elaborate land management schemes they adopted. ${ }^{4}$ Coalitions favoring greater state involvement in land use planning that formed during periods of perceived crisis have not remained intact. Many environmental groups (staunch supporters of state land use legislation) have lost the clout they once had. Localists (so-called "home rule advocates") who were defeated in their efforts to block state interference in local land use decision making have renewed their efforts with some success. ${ }^{5}$

Why has the trend toward state adoption of land use legislation (dubbed the "quiet revolution in land use controls") come to a halt? Why have the coalitions that supported legislative enactment of growth management legislation been unable to sustain the pressure needed to guarantee successful implementation of the laws for which they lobbied? One view is that land use legislation was framed too narrowly-as just another tool for environmental protection. The recession of the mid-1970s and the business interests' campaign charging that environmental legislation has hurt the economy have reduced the effectiveness of the environmental lobby. Thus, support for land use legislation has dimmed. In addition, coalitions supporting state land use legislation have been delicate. Labor organizations (believing that involvement in land use planning could overcome restrictive local zoning practices and accelerate housing production), good government groups (believing that a shift to state control would diminish the power of inept local officials), and industrial development groups (believing that state coordination of land use planning with other state investment and regulatory efforts would make development easier) teamed up with environmental organizations (believing that only higher government levels would be tough enough to enforce strict standards for environmental protection) to push for state land use and growth management legislation. Typically, the legislation that passed promised something for everyone. When it came time, however, to prepare detailed land use policies or to impose restrictions on certain environmentally sensitive areas, the coalitions fell apart. Every group could not have what it wanted. Almost no effort at public education preceded the passage of land use legislation in most states and no lasting constituencies were built to fight for implementation of enacted bills.

The Congress and President Carter have not supported a strong federal role in land use planning, preferring greater state involvement. ${ }^{6}$ Future efforts to enhance the state's role in land use planning will require more elaborate public education efforts. Land use issues must be presented as political is-

4. R. Linowes \& D. Allenworth, supra note 1 .

5. The distinction between environmentalists and localists was first made by $\mathrm{J}$. Coke and $\mathrm{S}$. Brown, Public Attitudes About Land Use Policy and Their Impact on State-Policy Makers, 6 Publius 97-134 (1976).

6. Personal conversation with Secretary of the Interior, Cecil Adrus, Vail, Colorado, August 1977. 
sues of great concern to everyone and not merely as technical issues of interest only to environmentalists or real estate brokers. Great care will have to be devoted to the design of new intergovernmental planning arrangements that can withstand the pressure that is exerted when it comes time to implement site-specific policies or growth management restrictions. Durable coalitions will have to be formed.

The 1975 Massachusetts Growth Policy Development $\mathrm{Act}^{7}$ respected these new ground rules. The Act sought to re-order the sequence of events that typically precedes the call for the expansion of the state government's role in land use planning. The Act emphasized the need for public learning, as opposed to ad hoc responses to impending crisis.

In October 1977 the Massachusetts Office of State Planning (OSP) published City and Town Centers: A Program for Growth, summarizing the results of the Massachusetts growth policy development process. The OSP Report contained over thirty action-recommendations. The specificity of the recommendations and OSP's clearly articulated "centers strategy" made this unique among state land use and growth policy reports. Within a year, twenty of the recommendations had been implemented successfully through the enactment of seventeen different pieces of legislation and various administrative actions. Twelve other recommendations are the subject of legislation pending before legislative committees. The new state administration (elected Autumn 1978) has different growth management and development priorities from the previous administration. Nevertheless, Governor King has endorsed the thrust of the OSP Report (although he dismantled the cabinet-level Office of State Planning created by his predecessor). The Massachusetts legislature is currently considering a new bill, the Massachusetts Balanced Growth and Development Act, that would alter state, regional, and local planning and regulatory relationships along the lines suggested by local growth policy committee members. The concepts and policies that emerged from the growth policy process are now part of the mainstream of Massachusetts politics.

The purpose of this article is to trace the evolution of the Massachusetts approach to growth policy, to examine how it operated, and to evaluate its results. To do this, we will outline the context of growth problems in Massachusetts and examine the legislative history of the 1975 law and the public policy theory behind it.

II

\section{The Massachusetts Context}

As of 1977, demographic and economic conditions in Massachusetts reflected an almost contradictory combination of growth and decline. In 1970, Massachusetts was the third most densely populated state in the nation, with

7. Codification of an Act Providing for the Formulation of a Massachusetts Growth and Development Policy, ch. 807, 1975 Mass. Acts 1102. 
727 people per square mile (over twelve times the national average of 57.5 persons per square mile). ${ }^{8}$ Between 1960 and 1970 , the rate of population growth in Massachusetts (10.5\%) was slightly below the national average $(13.3 \%)$; and considerably below that of the nation's most rapidly growing states, which increased between 20 and 30 percent during the same period. ${ }^{9}$ Between 1970 and 1975 the below-average trend of population growth became more pronounced as Massachusetts grew by only 2.4 percent while the rest of the nation grew at more than twice that rate. ${ }^{10}$ The percentages, however, are a bit misleading. While Massachusetts did not encounter significant growth rates between 1960 and 1970, the Commonwealth's population increased by 540,000 . Only twelve other states in the nation added more people during that period. ${ }^{11}$ Between 1970 and 1974, another 100,000 people were added, bringing the state's population to $5,789,478 .{ }^{12}$

This situation was complicated further by the regional distribution of additional population growth. Almost 90 percent of Massachusetts' citizens live in the eastern half of the state. Intrastate densities range from over 20,000 people per square mile in some parts of the metropolitan Boston area to less than 50 people per square mile in rural western communities. ${ }^{13}$ The state's population continues to become more suburban and exurban. During the 1960s nine of the state's fourteen central cities recorded absolute declines in population. Simultaneously, suburban populations increased by 24.8 percent and towns outside standard metropolitan statistical areas (SMSAs) increased by 24.5 percent. ${ }^{14}$ This trend continued through the first half of the seventies, with central cities losing population, suburbs increasing more slowly than their 1960 rates, and exurban communities increasing more rapidly than they had during the sixties. At the same time, the smallest rural communities either lost population or remained at their 1960 level.

Between 1951 and 1971 land in urban use increased from 420,000 acres to 780,000 acres, an increase of over 85 percent. $^{15}$ During the same period, pop-

8. U.S. Bureau of the Census, 1970 Census of Population, Number of Inhabitants United States Summary PC(1)-A-1, Table 11, at 52 (1971) [hereinafter cited as 1970 Census]; U.S. Bureau of the Census, 1978 U.S. Statistical Abstract. Table 12, at 12, 13 [hereinafter cited as Statistical A bstract].

9. 1970 Census, supra note 8, Figure 23; Statistical Abstract, supra note 8.

10. U.S. Bureau of the Census, cited in A Standout State in a Hard-Luck Area, U.S. News \& WORLD REP., Dec. 20, 1976, at 38 .

11. 1970 Census, supra note 8, Table 15, at 1-59.

12. Bureau of Research and Statistics, Massachusetts Dep't of Commerce and Development, Massachusetts Population, March 1, 1975 State Census.

13. Bureau of Research and Statistics, Massachusetts Dep't of Commerce and Development, Population Area Density, 1970 (Feb. 1971).

14. Our calculations from G. Hornig, Population Growth and Distribution in Massachusetts: Past, Present and Future, 1950-1990, (unpublished paper prepared for the Massachusetts State Land Use Program, Harvard University Center for Population Studies) (Sept. 1974).

15. Office of State Planning, Commonwealth of Massachusetts, Towards a Growth Policy for Massachusetts 5 (October 1975). 
ulation increased by only 21 percent. ${ }^{16}$ This means that population growth during the past two decades has consumed four times the amount of land per capita as that consumed by previous development. Between 1960 and 1970 , land in eastern Massachusetts was developed at the rate of one-half acre for every additional person (before World War I, the rate was one-eighth of an acre per person.) The supply of farmland in Massachusetts has steadily declined from 2 million acres in 1945 to about 700,000 acres in 1976. Massachusetts will lose 20,000 acres or 200 farms per year if state-wide action is not taken. ${ }^{17}$

The loss of agricultural land represents more than a change in land use patterns. Each year Massachusetts imports over $\$ 3$ billion worth of food. ${ }^{18}$ High food costs are only one expense that makes the Boston consumer price index the highest of any mainland city in the United States. Even more significant are high energy and transportation costs which have combined to place the Massachusetts economy in its worst condition in decades. By almost every indication, the Massachusetts pattern of economic growth has lagged behind that of the rest of the nation for the past decade. Between 1970 and 1975 the Massachusetts unemployment rate increased from 4.6 percent to 12.4 percent while the national average increased from 4.9 percent to 8.5 percent. ${ }^{19}$ The state's transformation from an industrial to a service-based economy accounts for much of the unemployment. From 1960 to 1971 , manufacturing employment in Massachusetts decreased by over 100,000 jobs from 695,600 to $594,300 .^{20}$ In the early $1970 \mathrm{~s}$, the state lost another 59,100 manufacturing jobs, while service jobs increased by nearly 145,000 for the same period. ${ }^{21}$ In 1973 over 60 percent of the Commonwealth's jobs were in the service sector. Thus, high unemployment rates in Massachusetts reflect, in part, a mismatch between the skills of the labor force and the needs of new business. Consequently, while other parts of the country have recovered from the effects of the recent recession, structural transformations and high operating costs have caused the Massachusetts economy to respond more slowly.

As population trends vary across the Commonwealth, so do economic conditions. Unemployment is highest in the state's large cities and in the

16. Id. at 7 .

17. Dep't of Food and Agriculture, Commonwealth of Massachusetts, A Policy for Food and Agriculture in MassachusetTs 5 (1976).

18. Special Commission on the Effects of Growth, H. 5339, Preserving Massachusetts' Prime Agricultural Land: Second Interim Report of the Special Commission on the EfFECTS OF GRowTh 13 (April 16, 1976).

19. U.S. Bureau of Labor Statistics, Dep't of Labor, Commonwealth of Massachusetts Division of Employment Security Research Department in Commonwealth of MasSachusetts Point of View (May 20, 1977).

20. R. Gamse, R. Gippin \& M. Ramsdell, The Impact of State Policy on Industrial Plant Location Decisions and Job Development (unpublished paper prepared for the Massachusetts Legislative Committee on Commerce and Labor, May 1972), at 11-1.

21. The Business Climate in Massachusetts, Boston Globe, June 6, 1976, § E, at 7. 
medium-size centers in the western part of the state. Service sector growth is located predominantly in eastern suburban communities. These differences have resulted in significantly different priorities in various communities.

Population shifts and economic conditions provide only part of the picture. The state has a long history of local self-government and municipal autonomy. This tradition is symbolized by the town meeting form of government which is over 300 years old in many localities. Unlike other, less urban states, all Massachusetts land area is included in either incorporated cities or towns. County governments play little or no role. In addition, 90 percent of all local governments have adopted land use regulations, usually in the form of zoning or subdivision controls. ${ }^{22}$ The local autonomy tradition was further strengthened in 1966 by adoption of the Massachusetts Home Rule Amendment. ${ }^{23}$ The Amendment gave localities the power to act on any matter not expressly preempted by the state constitution or legislative enactments. At present, localities view the control of growth and land use as a local concern. Consequently, attempts by the state government to influence land use or growth patterns have been greeted with great skepticism and resentment.

The home rule tradition and the skepticism toward state intervention must be contrasted with another trend in Massachusetts government. The state government has a long history of progressive social reforms and is known as one of the most innovative state legislatures in the nation. In 1971, when The Quiet Revolution in Land Use Control was published, Massachusetts was recognized as one of a select number of states leading the nation in the adoption of innovative state-wide land use regulatory mechanisms. ${ }^{24}$ The 1969 Massachusetts Zoning Appeals Law was the first attempt by any state legislature to overrule local exclusionary zoning. ${ }^{25}$ Massachusetts also pioneered in wetland protective legislation with a number of "model" statutes between 1963 and $1972 .{ }^{26}$ In 1973, the Massachusetts Environmental Policy Act required that all projects involving state money or requiring state approval had to be reviewed for potential impact on the environment. ${ }^{27}$ In 1974, "An Act Protecting the Land and Water of Martha's Vineyard" established the nation's first regional land

22. D.R. Dwight, Land Use in Massachusetts in Proceedings of Setting a Statewide Land Use Policy (R. Kreplick, W. Litsky \& H.B. Gunner eds. 1974).

23. Mass. Const., art. $88, \S \S 6-8$.

24. F. Bosselman \& D. Calles, The Quiet Revolution in land Use Control (1972).

25. Massachusetts Zoning Appeals Law, 1969 Mass. Acts 712-15. Also known as the Anti-snob Zoning Act: see Austin, Yoshida \& O'Conner, Subsidized Housing and the Anti-snob Zoning Act, in The Land Use Controversy in Massachussetts: Case Studies and Policy Options 11-23 (L. Susskind ed. 1976) [hereinafter cited as The Land Use Controversy].

26. Massachusetts Wetland Protection Acts, Mass. Gen. Laws ANN., ch. 131 , §§ 40 \& $40 \mathrm{~A}$ (West Supp. 1979). See Wilbur, Smith \& Rubenstein, Protecting Inland Wetlands and Regulating Development in Areas of Critical Concern, in The LAND Use Controversy, supra note 25, at 135-46.

27. Massachusetts Environmental Policy Act, Mass. Gen. Laws ANN., ch. 30, \$§ $61-62$ (1978) (West Supp. 1979). 
use commission with the power to overrule local zoning laws. ${ }^{28}$ In recent years, the legislature has enacted bills dealing with scenic rivers, scenic mountains, and public utility sites that give state agencies power to override specific local decisions.

Numerous state agencies carry out uncoordinated programs that indirectly shape land use and growth patterns (e.g., transportation investments, air and water quality management, school aid reimbursement formulas, tax policy, etc.). There are several explanations for what appears to be a contradiction between local resistance to state interference in land use decision making and the enactment of various statutes which give the state override power. One view is that all of these bills won legislative support because they provide for substantial local involvement in their administration. The Wetlands Protection Act, for example, is administered by local conservation commissions. Another view is that all of the statutes mentioned (except the Zoning Appeal Law) are aimed at environmental protection which had a strong lobbying force through the early 1970s. Many observers believe that these bills would not pass if introduced today.

The demographic, economic, and political conflicts outlined above characterize the setting in Massachusetts prior to the enactment of the Growth Policy Development Act. Equally complex forces are evident in every other state as well. The reason for presenting them here is to indicate the pitfalls and complexities that confronted the advocates of the Growth Policy Act.

III

\section{Legislative History of the Growth Policy Development Act}

\section{A. The Creation of the Special Commission}

In August 1973, the Massachusetts General Court responded to the above conditions by creating the Special Commission of the Effects of Growth Patterns on the Quality of Life in the Commonwealth (Chapter 98 of the 1973 Resolves. $)^{29}$ The Commission resulted from a resolution filed by Rep. Robert D. Wetmore. This Commission was given a broad mandate to study a variety of issues including: demographic and population trends, the preservation of agricultural land and open space, the supply and utilization of the state's land and natural resources, and methods of community, regional and state planning. The legislature adjourned in November 1973. For almost a year, the Commission remained relatively inactive.

28. Ch. 637, 1974 Mass. Acts, 618-31. See Barrs, Nelson \& Taipale, The Prospects for Regional Cooperation, in The LAND Use Controversy, supra note 25, at 53-68.

29. Resolve Providing for an Investigation and Study by a Special Commission Relative to the Effect of Present Growth Patterns on the Quality of Life in the Commonwealth, ch. 98, 1973 Mass. Acts. 1696 
In 1974 the General Court was deluged with bills dealing with land use, growth, environmental protection, economic development and proposals to reorganize planning responsibilities. Many of these bills were referred to the Commission, named the "Wetmore/McKinnon Commission" after its House and Senate chairmen. The Commission had to divide and structure its work due to the scope and variety of problems over which it had jurisdiction. In June 1974, the Commission enacted a series of by-laws and created four investigative subcommittees dealing with: (1) growth policy, (2) land use, (3) demographic information, and (4) public education. Chairmen were appointed for each subcommittee and directed to analyze proposed legislation and undertake activities necessary to prepare reports, recommendations, and legislative proposals for review by the full Commission. Since the Commission was unfunded, it relied on voluntary staff support from a variety of state agencies, interest groups, and educational institutions. The subcommittees varied in their ability to attract outside staff support and to generate citizen interest. Eventually, the Public Education and Demographic Information subcommittees dissolved. The Growth Policy Subcommittee held a series of monthly hearings, but produced no final report. The Land Use Subcommittee was the only one able to maintain sufficient momentum to produce a final report and legislative recommendations.

The success of the Land Use Subcommittee resulted primarily from the fact that its chairman, Senator William L. Saltonstall, was able to convene over fifty representatives of business, industry, labor, environmental organizations, state, regional and local officials, and the academic community to discuss "land use headaches in Massachusetts." In August 1974, Saltonstall secured staff commitments from the Department of Urban Studies and Planning at the Massachusetts Institute of Technology and from the state Department of Community Affairs. With staff assistance, he was able to translate the "headaches" noted at the first two subcommittee sessions into an agenda of biweekly meetings at which specific land use and growth-related issues were discussed. The committee memership's diversity and the desire of interest groups to present and contrast their views on land use and growth policy issues contributed to an ongoing dialogue that resulted in legislation.

\section{B. The Initial Meetings of the Land Use Subcommittee}

The subcommittee's work eventually divided into two phases. The first phase, from August 1974 through February 1975, focused on an analysis of the nature and causes of land use and growth management problems confronting the Commonwealth. The second phase, lasting from March through June 1975, focused upon alternative solutions to land use and growth management problems, on analysis of bills previously submitted to the General Court, and the drafting of a new legislative proposal.

During the first phase, membership of the subcommittee grew to over 100 . 
The group considered issues such as: the strengths and weaknesses of local land use controls, the role of regional planning agencies and middle-level government in land use decision making, current state-wide land use controls, economic development, agricultural land and open space, and the re-use and revitalization of central city land. Six major interest groups emerged during these meetings:

1. Environmentalists who wanted either strong state or regional control over land use and growth policy decisions;

2. Promoters of economic development, predominantly business, industrial and labor leaders who felt that existing environmental legislation was responsible in part for the state's economic woes and wanted to insure that no further restrictions were placed on development opportunities;

3. Home rule advocates who viewed land use and growth policy solely as a local responsibility and did not want the state to preempt their authority;

4. Officials from various state agencies vying for control over land use matters;

5. Staff of the regional planning agencies lobbying for greater authority at the regional level, and;

6. Advocates of compromise who were looking for a balance between economic development, environmental preservation, state and local control.

Each group presented its position, questioned others concerning their viewpoints, and tried to define more carefully the land use and growth management problems facing Massachusetts. In essence, the subcommittee meetings resulted in the explicit examination of the values and assumptions underlying alternative positions on land use and growth policy issues. At first each group tried to sell its own position without listening to other points of view. The conflict level was high and the trust level was low. After six months of biweekly meetings, perceptions slowly began to change. Trust and openness levels among subcommittee members began to increase. Different interest groups worked harder to understand others' positions. Clearer understanding resulted in the realization that the positions of the various groups were not as irreconcilable as they first seemed.

Home rule advocates, for example, conceded that a variety of state policies and programs had a substantial influence on local growth patterns and that policy coordination between local, regional and state governments would be necessary if growth problems were to be resolved. State officials admitted that many existing state policies might be contradictory and have unanticipated impacts on local growth patterns and conditions. Several state legislators indi- 
cated that input from localities would be helpful in evaluating the land use impacts of existing programs and suggesting policy revisions. Economic development advocates confirmed their perception about the need to revise the existing regulatory system. Instead of viewing attempts to formulate new land use policies as another possible deterrent to economic development, they began to see how reform efforts might stimulate development and make the permit and regulatory process more efficient. Environmental advocates could document the economic benefits stemming from various environmental protection efforts and agreed that the state needed well planned economic and residential growth which would provide jobs and housing while respecting the state's unique and sensitive environmental areas.

\section{Building a Coalition}

These changing attitudes led to the creation of a coalition among subcommittee members who felt that the state could coordinate more effectively the existing policies affecting land use and growth management. They also agreed that new policies should reflect the direct involvement of a large number of Commonwealth communities and citizens. Coalition members were predominantly state legislators, local officials, representatives of homebuilding and manufacturing interests and moderate environmentalists. The coalition focused its legislative efforts on five key problems, summarized as follows:

1. Many localities have not come to grips with the problem of charting development and conservation priorities;

2. Many localities are facing serious growth management problems (such as inadequate water supply, solid waste disposal problems, traffic congestion, spiralling tax rates, loss of prime agricultural land, etc.), which are beyond their power to control;

3. Important, but unwanted regional facilities are being boxed out by individual communities which understand the need for such improvements, but do not want to shoulder the burden of additional development;

4. Critical natural resource areas are threatened by development which individual communities are either unwilling or unable to control. Moreover, the effects of unplanned development in one community are spilling over into neighboring municipalities; and

5. State investment programs and regulatory policies have not been sufficiently responsive to local and regional needs and are to blame for some of the growth management and land use problems that cities and towns now face. ${ }^{30}$

The coalition decided that it might be appropriate for the state to encourage cities and towns to submit annual planning statements which would outline current approaches to development and environmental protection, spell out

30. Personal notes from April 24, 1975, meeting of the Land Use Subcommittee of the Special Commission on the Effects of Growth. 
the steps that each community intended to take to address priority needs, and analyze the impact of state policies on existing growth patterns. These local statements would form the basis for regional and state land use policies. This approach placed as much emphasis on the process of local participation in articulating land use policies as it did on the policies that might emerge. This concept of annual planning statements led to the approach embodied in the Massachusetts Growth Policy Development Act.

Although the coalition which developed these ideas dominated the Land Use Subcommittee, there was still a substantial minority which did not agree with the so-called "bottom-up" approach to land use and growth management policy formulation. This group consisted of the representatives of certain state agencies, staunch environmentalists, and many representatives of the regional planning agencies. A number of state agencies were competing for top designation as the state's land use agency. They had been involved actively in the land use debate for several years. When confronted with the notion of legislation that would involve citizens and local officials in land use policy making, they argued that growth management problems were well understood and what was needed was not "another study," but administrative action. They condemned the idea of local growth policy statements and substantial citizen involvement as siphoning energy from the things that needed to be done, i.e., the designation of a lead land use agency and (possibly) a mechanism for state or regional review of local land use decisions.

These officials sided with a strong environmental group which argued that the approach suggested by the coalition would not address the state's critical environmental needs. The environmentalists wanted to submit legislation that would require the identification of areas of critical environmental concern and developments of regional impact and that would give regional and state officials the authority to overrule local decisions in such areas. They cited the Martha's Vineyard Bill as a model. In addition, the environmentalists accused the coalition of endorsing a weak concept simply because it had a better chance of winning legislative approval. They argued that the regional critical areas approach would, at least, offer a strong land use bill and would serve as a public educational device even if it did not pass. On the other hand, the coalition's "process-oriented" approach was viewed as a diluted compromise among groups with such divergent interests that it would have no significant impact on land use or growth policies.

Finally, regional planning agencies had been advocating reform of midlevel government in Massachusetts. The Commonwealth has a weak system of county governments and thirteen Regional Planning Agencies (RPAs) whose primary purpose is to permit cities and towns to plan jointly and to coordinate the orderly development of their jurisdictions. Regional planning agencies only have advisory power, somewhat enhanced by their A-95 clearing 
house role. ${ }^{31}$ Representatives of regional planning agencies; therefore, joined state officials and environmentalists in advocating land use legislation that would enhance the power of regional authorities. Regional planning officials also maintained that communities and local citizens did not take advantage of existing participatory opportunities at the regional level and that a state-wide participatory process would fail from lack of interest unless strong sanctions were imposed.

Thus, by late February 1975, the Land Use Subcommittee had split into two relatively distinct factions. Each group had its own idea of the land use bill the Massachusetts legislature ought to adopt. The subcommittee continued to meet as a whole to analyze land use related bills which were submitted to the Commission for review. In addition, each faction began to draft its own legislative proposals.

At this point the impact of the gubernatorial election became important. On February 27, the new Governor, Michael S. Dukakis, met with the Commission to announce the creation of a new Office of State Planning (OSP). The Governor gave this office principal responsibility for land use, growth policy and comprehensive planning for the state. He indicated that he would instruct the new OSP to generate a state master plan. This master plan would be used to guide the allocation of state funds and help to identify appropriate areas for development and preservation. Although the OSP was formally a part of the Executive Office of Administration and Finance, the Governor made its director an ex-officio member of the cabinet, reporting directly to him. In addition, the Governor informed the Commission that he did not see the need for new land use or growth policy legislation. He stated that the Commonwealth had a number of effective pieces of land use legislation and that the role of OSP would be to coordinate existing state planning activities, prepare a master state plan, and make existing regulatory legislation work. In essence, the Governor's message to the Commission was that he intended to take an administrative approach to the resolution of land use and growth management issues.

To existing state agencies, strong environmentalists and regional planning officials this message indicated that the "turf battles" for the control of land use were over. In addition, the Governor's statement suggested that the possibility of passing a strong regionally oriented land use bill was low. While the advocates of a "strong land use bill" continued to work on state-wide legislation modeled after the Martha's Vineyard Bill, their strength rapidly dissipat-

31. The A-95 project review system was established by the Federal Office of Management and Budget (OMB) under the Intergovernmental Cooperation Act of 1968. 42 U.S.C. $\$ 4201$ (1976). Essentially, this system provides the opportunity for state and area-wide clearinghouse agencies to review applications for federal assistance. The intent of the program is to identify at an early stage conflicts between federally assisted projects and state and regional plans and policies. 
ed. On the other hand, the "process oriented" coalition was affected less seriously by the Governor's message. They maintained that it was one thing to say that a state master plan was needed and quite another to design a process by which such a plan could legitimately be produced. Basically, the coalition disagreed with the Governor's orientation toward a state-wide master plan. They were more convinced than ever that it would be possible to demonstrate the need for a "bottom-up" participatory planning process. Thus, they continued their efforts to forge an agreement with the advocates of strong regulatory legislation.

The MIT staff outlined a bill which attempted to merge the concept of local annual planning statements with the regulatory concerns of the "strong bill" coalition. A series of formal and informal meetings was scheduled to discuss alternative legislative approaches. These meetings were aimed at reaching a compromise between the "process oriented" and "strong bill" coalitions.

\section{Growth Policy Legislation: The First Draft}

Each group met separately to draft a version of compromise legislation. The "process oriented" coalition produced a first draft entitled, "An Act Relating to Local and Regional Participation in the Formulation of a Growth Management and Land Use Policy for the Commonwealth." 32 It was built on the idea of annual local planning statements but had evolved into a proposed two-year process that would allow cities, towns and regional planning agencies to participate in the effort to formulate a state growth management and land use policy. The draft bill called for each of the 351 Massachusetts cities and towns to prepare a Statement of Growth Management Problems and Priorities. These statements would identify specific local developments with regional impacts and local areas of critical planning concern. Localities would be encouraged to comment on the ways in which land use-related activities of state agencies could be coordinated more effectively. Finally, communities would be asked to describe ways to minimize the time and cost involved in obtaining development permits and licenses. A municipality would be free not to supply this Statement, but complying communities would have first priority in the allocation of federal aids to planning (such as HUD 701 funds and other grants administered by the state government). Failure to comply would result in unfavorable state and area-wide A-95 reviews for subsequent federal grant applications.

Regional planning agencies would be asked to review local Statements and prepare composite Regional Reports describing regional growth management problems and priorities. These Reports would identify developments of regional impact and areas of critical concern from a regional point of view.

32. Commonwealth of Massachusetts, Proceedings of the Land Use Subcommittees of the Special Commission on the Effects of Growth Patterns on the Quality of Life in Massachusetts, at 14 (Spring 1975). 
Within eighteen months of enactment of the Bill, a designated state agency would prepare a Summary Report containing a review of the most pressing local and regional growth management problems and priorities. The Summary Report would include guidelines and standards for designating areas of critical planning concern and developments of regional impact as well as strategies for more effective coordination of the land use related activities of state agencies. Based on the local Statements and Regional Reports, the designated state agency would summarize recommended growth policies reflecting both local and regional preferences as well as state-wide concerns. The Summary Report would be submitted to a temporary ten-member commission composed of three members of the House of Representatives, three members of the Senate, and four secretaries designated by the Governor. Within twentyfour months of the effective date of the Act, the commission would submit growth management and land use policy legislation to the General Court. This legislation would be based on the Summary Report and on the commission's review of the material submitted by communities and regional planning agencies.

This Act was designed to ensure that localities and regional planning agencies were fully involved in the formulation of state-wide growth management and land use policies. It would guarantee that the criteria for defining developments of more than local impact and areas of critical planning concern reflected local and regional preferences. The Act would encourage extensive public participation in the setting of development and conservation priorities. The preparation of local Statements and Regional Reports would help to eliminate some of the obstacles and delays hindering development in areas where residents desired additional growth.

The Act called for the expenditure of no more than $\$ 20,000$ a year for two years. These funds would cover the costs of providing for local and regional participation. The bill sought to ensure that a state-wide growth management and land use policy would be formulated from the "bottom-up," but that strong legislation protecting critical environmental resources, encouraging economic development where it is most desirable and pulling together fragmented state planning and management activities would be forthcoming within twenty-four months.

The process oriented coalition considered this bill a compromise because it contained a strong orientation toward areas of critical planning concern and developments of regional impact. In addition, it contained sanctions against communities which did not prepare local planning statements.

\section{E. The Subcommittee Split Is Resolved}

The "strong bill" coalition prepared its own outline of compromise legislation. This draft outlined a new system of regional councils with strong 
planning and regulatory powers. Regional land use commissions would be responsible for the development of regional plans according to state guidelines. Regional plans would be certified by the state. Regional commissions would have the power to designate critical concern areas and to establish guidelines for local decisions in these areas. Each regional commission and its land use planning and regulatory process would be approved by a regional referendum. If the regions did not establish such a system within five years, the state would set up a regional commission.

On April 16, 1975 the two groups met as a special drafting committee to work out final legislation to present to the entire subcommittee on April 24. The atmosphere was tense. The "strong bill" proponents attempted to convince the subcommittee's leadership that the only solution to the state's land use dilemma was a total revision of the lines of authority in the existing regulatory system. The land use and growth management dilemma was defined as the inability of local governments to deal with land use decisions having greater than local impact. The policy solution was equally clear: state or regional override of local land use decisions. In essence, the "strong bill" coalition had taken the position that regionalization along the lines of a centralized American Law Institute (ALI) land use regulatory system was the least they would accept. In fact, this was a small concession since discussions of this type had received considerable attention during the previous legislative session. ${ }^{33}$

The "process oriented" coalition felt it had made considerable concessions by placing substantial emphasis on areas of critical planning concern, developments of regional impact and sanctions against communities which did not comply. The meeting was nearing conclusion when the "process oriented" coalition offered its final argument:

Social, environmental, economic and political conditions in the Commonwealth are changing rapidly. In the past, most of our legislation dealing with land use and growth policy on a state-wide basis has dealt with environmental problems (i.e., wetlands, scenic roads, rivers, sensitive coastal and mountain areas, etc.). Now we are faced with a situation in which economic decline is clearly the most highly perceived issue in the state. If we are to prevent environmental legislation from becoming the scapegoat for our economic problems, we must attempt to design legislation that will work towards balancing the needs for economic development and the needs for environmental protection. That is, we must encourage economic growth in areas in which it is appropriate and where people want it. At the same time, we must protect those areas which are most sensitive environmentally. Only a process that involves a large number of people from all levels of government will be able to formulate such policies and carry out their implementation. In the past few years, we have begun to see land use legislation in Vermont and Colorado come apart. The problems in these programs are largely due to the fact that eco-

33. Mass. H. 1047 (1974). Considered by the 1974 regular session of the Massachusetts House of Representatives. 
nomic and political conditions have changed; and there is no longer a viable state-wide coalition to support implementation efforts. A "bottom up" policy formulation process will do at least two things. First, it will lay the groundwork for developing a state-wide coalition for implementing any recommendations which may stem from the process. Second, it will create a local network which will allow the state government to respond to rapidly changing conditions and problem definitions. Local groups, for the first time, will be given a formal mechanism for assessing their changing needs and priorities and informing state and local government of alternative policy solutions which may better address their needs $\ldots{ }^{34}$

During the week of April 16-24, 1975, an event occurred that would prove to be one of the most significant factors in the passage of the Massachusetts Growth Policy Development Act. Governor Dukakis appointed Frank Keefe as permanent director of the OSP. This appointment marked the virtual dissolution of the "strong bill" coalition since several of its members had been pursuing control of the newly created OSP.

On April 24, Keefe met briefly with the Land Use Subcommittee. He expressed interest in coordinating state policies which affect growth, streamlining regulatory procedures which impede economic development, and focusing on strategies for revitalization of urban centers. Keefe reiterated the Governor's position that new land use and growth policy legislation was not necessary and that policy coordination and growth management issues could be handled administratively. He did, however, promise to review the subcommittee's draft legislation and committed himself to working with the subcommittee.

On April 27, Commission leaders met to consider the revised draft of the legislation. This meeting consisted of the chairmen of the Commission's subcommittees, Representative Wetmore and Senator McKinnon. The Commission leaders were extremely interested in the legislation and decided to have Frank Keefe review it, particularly in terms of its consistency with the goals of OSP.

During the next three weeks, the staff of the Land Use Subcommittee revised the draft legislation in response to written comments from subcommittee members and various interest groups. In addition, the staff met with Keefe and his staff in an attempt to convince the OSP of the validity of the "bottom up" approach. At first Keefe reiterated the Governor's position that, "No new legislation was needed, integration and coordination of state and local policies and planning could be handled administratively." The Land Use Subcommittee staff took the position that a joint legislative-administrative approach to the formulation of land use and growth management policies would be more effective than separate efforts by either group. They pressed the ar-

34. Personal notes from April 24, 1975 meeting of the Land Use Subcommittee of the Special Commission on the Effects of Growth. 
guments that had been used originally to support legislation in the Land Use Subcommittee. In addition, they suggested a new argument relating to the organizational objectives of the OSP. When established, the OSP was charged with the responsibility of coordinating state policy decisions, evaluating the impacts of existing growth related policies, and recommending policy changes. The staff of the Land Use Subcommittee argued that if the OSP was to succeed in its policy coordination efforts, it would need a constituency to support its decisions. Other state agencies whose policies the OSP would, more than likely, be challenging already had entrenched constituencies to support their policy decisions. Since many state policies seemed to have contradictory or negative impacts on localities, there was no more appropriate constituency for the OSP than the localities themselves. Through the "bottom up" growth policy formulation process, localities could express their needs and concerns and provide support for potential OSP recommendations to change existing policy.

In response to these arguments Keefe changed his position. The idea of a joint legislative-administrative endeavor appealed to him. The possibility of creating a state-wide coalition for planning and coordination of local, regional and state policy seemed to be within the mandate of his office. Keefe subsequently convinced the Governor that a master state plan, in the form of a map, would be virtually impossible to produce and was less important than a comprehensive planning process. In addition, he took the position that the subcommittee's legislation would attract public attention and increase public understanding of growth and development issues more successfully than administrative efforts alone.

\section{F. Governor Dukakis Lends His Support}

On May 22, Keefe met with the Commission leaders and indicated his support for a joint legislative-administrative approach to the formulation of growth and development policies for the Commonwealth. He requested two weeks to complete his review of the draft bill and to make recommendations to the Governor. In early June, Keefe sent a memorandum to the Governor detailing his thoughts on why the administration should support the "bottom up" legislation. Keefe's arguments in support of the legislation were:

a. The Commission and its Land Use Subcommittee have worked long and hard on this legislation and believe that a "bottom up" participatory approach is essential to the credibility and acceptability of any State-initiated ("top down") growth policy and management program.

b. It is the view of the Commission that all of this work will go for naught if the support of the Governor through the Office of State Planning does not emerge.

c. The local and regional participation necessary for the proper functioning of OSP's planning efforts could be enhanced and extended substantially by 
the enactment of special legislation which formally encourages such participation

....

d. The legislation, if passed, would put the General Court on record as concerned about the reconciliation of economic development and environmental protection as well as in the position of collaborators in the effort to improve the state's policies and programs for growth management.

e. The legislation is laudable in so far as it extends to the 351 communities and 13 regions the opportunity to participate in the development of growth policy and program evaluation at the state level. As such, it would serve the purpose of providing an effective response to any possible complaint that people at the local level were not involved in the process. ${ }^{35}$

Keefe made his support contingent upon Commission approval of the following revisions:

1. Remove all sanctions for communities that either choose not to take advantage of the opportunity to participate in the process or fail to comply with the schedule for completing the statement on growth problems and priorities.

2. Delete the requirement that the end result of the deliberations of the Office of State Planning and the Special Commission would be "growth management and land use policy legislation." It would be better if the submission of legislation were simply an option and not a requirement.

3. Adjust the proposed time frame so that the local statements would be prepared in three months, the regional reviews in one month, and the State's review by OSP (with summary and recommendations) within two months. This would not only convey a needed sense of urgency but conform better with the work schedule of the Office of State Planning, making this legislatively-provided participatory process supportive of the state's administrative leadership in improving growth management. [This was a drastic reduction of the bill's time-table from two years to approximately six months.]

4. Drop all mention of small grants from the state to communities to finance the preparation of the local statements. Instead, mention should be made of the opportunities for free technical assistance from the regional planning agencies and the Division of Local Assistance in the Executive Office of Communities and Development.

5. Replace the provision for endorsement of all local Statements by town meeting with a requirement that Boards of Selectmen be given an opportunity to submit a formal review and comment on the local Statements.

6. Insert a preamble to the legislation which describes the economic, environmental and social issues and concerns of poorly planned and mismanaged growth and development. ${ }^{36}$

On June 18, Mr. Keefe, Representative Wetmore, Senator McKinnon, and Senator Saltonstall met with Governor Dukakis to discuss the legislation and

35. Letter from Frank Keefe to Robert D. Wetmore, June 19, 1975. See Procendings of ThE LAND USE SubCOMmITTEE, supra note 32, at 12-13.

36. Proceedings of the Land Use Subcommittee, supra note 32 , at 13 
OSP's proposed revisions. At this meeting, the Governor endorsed the legislation, contingent upon the revisions suggested by the OSP.

The Land Use Subcommittee met on June 25 and considered a revised draft of the legislation prepared by OSP. This draft included all of OSP's proposed revisions. The Subcommittee reviewed the draft and suggested a number of changes. The most important change was the extension of the time schedule to at least eleven months (one month for the formation of committees, four months for the preparation of local statements, three months for regional reports, one month for preparation of the OSP report and two months for the commission report). Considerable concern was expressed over compressing the schedule even this drastically. The Subcommittee decided to send the modified OSP draft of the bill to the full Commission for approval.

On July 2, the Commission met and approved the June $25 \mathrm{draft}$ of the legislation. On July 21 , the Commission filed this legislation along with an interim report. The bill was entitled, "An Act Providing for the Formulation of a Massachusetts Growth and Development Policy." It was given House Number 6473 and sent to the Joint Committee of Commerce and Labor. The bill was sent to Commerce and Labor because the Commission leadership wanted to emphasize its concern with balancing economic development and environmental protection. It was not viewed solely as an environmental bill.

\section{G. The Hearings Process}

The Committee on Commerce and Labor scheduled a public hearing on the Bill for September 10, 1975. Between late July and early September, various Commission members and the Land Use Subcommittee staff continued to meet with a variety of citizens and interest groups including: representatives of the Massachusetts Homebuilders Association, Associated Industries of Massachusetts, the First National Bank of Boston, the Boston and Massachusetts Chambers of Commerce, Boston Edison, Massachusetts Shopping Center Developers, Jobs for Massachusetts, Massachusetts AFL-CIO, the Association of General Contractors, the Massachusetts Forest and Park Association, the Conservation Law Foundation, Audobon Society, Sierra Club, Massachusetts Association of Conservation Commissions, the Massachusetts Selectmen's Association, the League of Cities and Towns, the Massachusetts Association of Planning Boards, directors of the regional planning agencies, and others. By September, the Commission and its staff had mustered considerable support for the bill and had an excellent idea of revisions that would be suggested in the hearings.

At the hearings, numerous legislators, state, regional and local officials, representatives of economic and environmental interest groups and private citizens testified. All testified in favor, except the Massachusetts Selectman's Association, which was opposed to the bill in the form presented. They suggested that the local growth policy committees should be appointed by the 
Board of Selectmen rather than by the Town Moderator; that there should be a local review and hearings on the regional reports before their submission to the Office of State Planning; and that the final local growth policy Statement should be subject to the approval of the Board of Selectmen. In general, testimony at the hearing focused on the schedule. Almost everyone argued that the proposed timetable was too short and that local committees would need at least six months to complete their part of the process. Several business groups argued that the preamble of the bill was too negative and should be redrafted to emphasize the benefits that would stem from the formulation of state growth and development policies. Finally, several groups were concerned that the local growth policy committees would duplicate the efforts of local planning boards; others argued that there was no need to create a new Massachusetts Growth Policy Commission to perform the functions that could be handled by the existing Special Commission.

As a result of the hearing, a drafting committee composed of the staff and leadership of both the Commission and the Committee on Commerce and Labor met several times to redraft the bill. The final redraft included several substantive changes. As a result of these revisions, a final draft of the bill was agreed upon, given Senate number S.2087 and sent to the Senate Ways and Means Committee. This bill asked each city and town to establish a Local Growth Policy Committee consisting of the Mayor, City Manager or Chairman of the Board of Selectmen, the Chairmen of the community's Planning Board, Conservation Commission, Housing Authority, Redevelopment Authority and Health Department, the city or town Planner and at least five citizens representative of disparate social, economic and environmental interests. This committee was asked to prepare a statement of local growth management problems and priorities in response to a questionnaire from the Office of State Planning. The Committee would be required to subject its statement to community-wide review and debate and to hold at least two public hearings. Any citizen or group desiring to submit comments agreeing or disagreeing with the statement would be empowered to do so and these comments would have to be appended as part of the local report. Within six months of the effective date of the Act, the local Statements were to be sent to the OSP, the appropriate regional planning agency, and adjoining municipalities. At that time, regional planning agencies would be required to prepare a regional report summarizing the local Statements, highlighting conflicts and similarities among the local Statements, and identifying regional growth management problems and priorities. This report would be submitted to member municipalities for review and a public hearing on the report would be held. After the public hearing, the report would be revised and submitted to the OSP, the Special Legislative Commission and member municipalities. Regional reports were to be prepared within two months of receipt of the local reports.

The bill included specific guidelines to be used by the OSP in developing 
the questionnaire which would serve as the basis for the local Statements. In addition, it contained a list of issue areas to be emphasized in OSP's development of guidelines for the regional reports. The bill required OSP to analyze all of the local Statements and regional reports and to prepare a report to the Special Commission on Growth Patterns. This report would summarize the responses contained in the local and regional Statements and recommend policies and administrative actions in response to local and regional recommendations and perceived state-wide needs.

Finally, the Special Commission would receive the local, regional and state reports and all citizen comments. From this material, the Commission would prepare a report for submission to the General Court and the Governor, including both legislative and administrative recommendations reflecting, to the maximum extent feasible, the responses of the local, regional, and state reports. The bill specified that the Commission report should include but not be limited to discussion of the following four areas:

(a) standards and, where appropriate, new mechanisms, instrumentalities and processes to guide growth and development into those areas where they will be most desirable to facilitate community revitalization, to generate new economic vitality, to minimize adverse environmental effects and to conserve open land and natural resources;

(b) criteria for identifying areas of critical planning concern and developments of regional impact;

(c) approaches for minimizing the time and cost of obtaining all permits and licenses and completing all review procedures required for development; and

(d) strategies for coordinating the activities of state agencies involved in the allocation of state and federal funds for economic development, capital improvements, open space conservation and other activities related to land use.

Each element shall incorporate locally and regionally proposed standards insofar as they may be internally consistent. ${ }^{37}$

This final draft of the bill made clear that the process was not calling for massive data collection or elaborate technical studies. It emphasized that the process was aimed at documenting local attitudes and priorities.

S.2087 consisted of the basic components outlined above when it came before the Senate Ways and Means Committee. Due to the efforts of Saltonstall and McKinnon, the bill moved quickly from committee to consideration by the full Senate. On the Senate floor it received routine consideration. On October 14, the bill passed the Senate and was sent to the House Ways and Means Committee. On December 3, the bill was considered by the full House. After first reading, the home rule lobby actively organized its opposition. The bill was read for a second time and prior to any debate, Representative Demers moved to postpone consideration of ordering the bill to a third reading until after disposition of the remaining matters contained in the Orders of

37. Mass. S. 2087 (1975), at 13, (1975 Regular Session of the Mass. Senate). 
the Day. Representatives Demers and Wetmore were taking no chances. Earlier that year, the home rule lobby had effectively delayed the passage of revisions to the state's Zoning Enabling Act for over three months. Such a delay at this date in the 1975 session would kill the bill. Wetmore and Demers wanted to be certain of their supporters before the bill moved into debate. They spent the rest of the day securing reassurances of support from the leadership and the other representatives.

At the end of the day, the bill was considered. Representative Colo of Athol, a community of 11,000 in the central part of the state, spearheaded the opposition. Colo moved that the bill be amended by striking the word "shall" from Section 3: "there shall be created in every municipality in the Commonwealth a local growth policy committee"-and replacing it with the word "may." In debate, Colo argued that the bill would not provide local input into state policy making, but would result in information, generated by communities, being used against them to promote a system of state-wide zoning. He therefore contended that each community should be given the option of participating. Replacing the word "shall" with "may," he argued, would insure that localities had the option of not participating.

Representative Wetmore countered that participation was optional. He contended that there were no sanctions for nonparticipation and that neither the OSP nor any other administrative agency could take action against communities which chose not to participate. In addition, Wetmore argued that a number of state policies already had extensive effects on growth patterns in every community in the Commonwealth. Furthermore, the administration was beginning to review many of these policies and to formulate comprehensive growth and development plans for the state. Therefore, Wetmore contended that the Growth Policy Development Act would insure that communities and the General Court would have significant input into that policy review. Privately, Wetmore was not opposed to Colo's amendment. He wanted the process to be totally optional.

Representative Colo tried repeatedly to amend the bill. He moved to amend by adding a new section providing that the legislation would only take effect in a city or town by virtue of a vote by the City Council or Board of Selectmen. Colo repeated his earlier arguments about home rule, the threat of state-wide zoning and the need to let localities decide whether or not they would participate. He warned that the localities were tired of the state telling them what to do and that this bill was simply the first step toward even greater infringement on local authority. Wetmore, however, ended the debate by saying:

This legislation is not an attempt to reduce local autonomy. It is an effort to enhance planning capabilities of all levels of government. In the past, much of the land use and growth policy legislation that the General Court has reviewed was based on a predetermined notion that the state government knows 
precisely what Massachusetts' land use and growth management problems entail. In fact, one of the primary assumptions in previous legislative approaches was that local governments are incapable of dealing with certain types of problems. In contrast, our Commission decided to ask the people of Massachusetts what they think the most important growth and development issues are. We've asked the citizens to help governmental officials to balance our needs for both economic development and environmental protection. We want future growth and development policies to reflect the needs and concerns of citizens and communities throughout the Commonwealth. This effort to involve local officials and citizens in the preparation and evaluation of state-wide growth and development policies is unparalleled by any state in the nation. Cooperation between the executive and legislative branches in the development of this Bill has been outstanding. If the Bill passes, this cooperation is insured of continuing. State growth and development policies are as much of a responsibility of this General Court as of the executive branch. We now have the opportunity to develop coordinated growth policies for the state which will reflect local and regional concerns and have the backing which they need to be effective. For these reasons, I strongly urge passage of the Bill. It does not infringe on local home rule. Quite the contrary, it seeks to ensure that the cities and towns will have substantial impact on their own and the state's future growth patterns. ${ }^{38}$

Representative Colo's amendment was defeated by a vote of 85 to 136 and the bill was passed and engrossed. On December 22, 1975, Governor Dukakis signed the Massachusetts Growth Policy Development Act into law.

\section{IV}

\section{Theoretical Foundations of The Legislation}

With the Governor's signature, the first phase of the Commission's effort to initiate a comprehensive planning process for the State of Massachusetts came to a close. Simultaneously, however, implementation of the legislation marked an important next step. In order to understand the Massachusetts Growth Policy Development Act, one must realize that the legislation was viewed by its proponents as an initial step which would lead to a new outlook toward planning and implementation of a policy formulation process involving all levels of government in the Commonwealth. As indicated above, the legislation itself was not viewed as a solution to the many land use and growth management problems confronting Massachusetts. Instead, the Act was intended to initiate an innovative process that would lead not only to more effective responses to growth management needs, but also to a continuing state-wide commitment to land use planning and growth management.

This new legislative procedure is best characterized by its "inductive" approach to "public learning"39 and is best understood by contrasting it with the

38. Personal notes from December 3, 1975 session of the Massachusetts House of Representatives.

39. See D. Schon, The Technology of Public Learning (February 1974) (unpublished paper available at the MIT). 
traditional approach to policy formulation and implementation implied by most government programs. Donald Schon has characterized the traditional approach as follows:

[W]e have tended to conceive of planning and policy making, deciding and social action according to a paradigm so natural to us and so taken for granted that we do not even have a name for it; I propose to call it the model of rational purpose. This model has many variations, but its main themes have dominated policy making and planning in recent decades in [both] government [and] corporations ... .40

Schon contends that the model of rational purpose is seriously inadequate to the conditions of rapid change that characterize modern society. He claims that change is endemic to the 20th century and makes it impossible for "one central point in society to plan, to make policy, to decide for the rest of society and then to diffuse its solutions throughout the society." ${ }_{11}$ In this context, Schon argues that the key weakness of the rational purpose model is its reliance upon a "central-peripheral" approach to policy formulation and implementation. Schon has summarized the key weakness of this approach as follows:

Public problems are somehow given. The model assumes them as named and leaves mysterious, or at any rate unexamined, the process by which they came to be named. Somehow, we have been confronted with a series of crises -those, for example, of "poverty," "welfare," "transportation," "housing," "the cities," "health," "environment" and "energy." Once these crises have impinged on the public consciousness, the process of governmental intervention begins.

Given a public problem, it is studied. Study may take the form of a Presidential Commission, an agency initiative, a legislative committee. From these studies recommendations for policy are somehow derived and proposed to an appropriate agency of government-usually, the legislative branch, either because funds must be authorized and appropriated or because sanctions must be established for violation of law.

Once proposed, the policy is subject to hearings and to debate. It is assumed that various interest groups will have their say. Conflicting views about the policy are integrated in the process of legislative design. Funds for the implementation of policy are authorized and appropriated.

The legislative branch remains in a monitoring role, seeing to it that the executive branch carries out the tenets of the policy. [The legislative branch may carry out its quality control functions through an independent arm of government (in the U.S., the Government Accounting Office) to see to it that funds are expended for the purposes intended, and with fiscal probity.]

40. Id. at 1 . The paradigm of rational purpose views policy formulation primarily as a direct response to an immediate crisis. Public problems are defined in terms of immediately perceived crises. Central agencies are assumed to have a monopoly on the technical capabilities needed to analyze public problems and to determine the most cost-effective solutions. Centrally proposed policies are then, presumably, implemented by gradual diffusion through local governmental units.

41. Id. at 2 . 
The appropriate executive agency then takes on the task of policy implementation.

It is the business of this agency to design a program to carry out the policy, and to see that the policy is broadly diffused throughout the nation. Program development may include the running of small-scale experiments or pilots (such as those recently conducted for "negative income tax" and for "housing allowances"). From these smaller efforts, large scale programs are derived. Programs may take the form of requests for voluntary compliance with a principle (as in the case of voluntary industrial limiting of imports, for balance of payments purposes, in the Johnson administration); passage of a law, requiring compliance, on penalty of negative sanctions (as in the case of automotive safety and environmental protection legislation); or generation of a positive program aimed at creating new services, or modified or expanded services, in response to the problem (as in the case of Welfare legislation, the Safe Streets Act, Housing Subsidies, Health Maintenance Organizations, and the like).

In the last case, the agency usually solicits proposals from the localities according to a pattern roughly as follows: Guidelines are established. Proposals are solicited. Funds are used as "carrots" and "sticks" to induce design of proposals for programs in conformity to policy, and later, to induce implementation of programs as designed. Evaluation is assigned to an independent agency which sets out, post facto, to determine whether the program was carried out as intended and, perhaps also, to discover which variants of the program were most effective. On the basis of evaluations, the agency adjusts its allocation of funds. Periodically, the agency reports to the legislative branch on its accomplishments; and on the basis of these reports, and its own independent evaluations, the legislature re-evaluates its own allocations of funds. ${ }^{42}$

The rational purpose model assumes that the appropriateness of the defined problem is given (the crisis is the problem). Second, the model assumes that the problem can be studied and policy conclusions derived from factual data. Third, it is assumed that through study, the government is capable of finding the "right answers" or "policy fixes," and of taking the needed action to solve the problem. Fourth, the model assumes that central can learn for the localities (in the sense of policy generation) and can teach the localities (by encouraging them to implement the appropriate policy response). Finally, the model "assumes that [through careful evaluation] central can and will detect deviations from [the] right policy, can diagnose mistaken policies [or inappropriate local implementation] through retrospective inquiry, and can incorporate the learning from these activities into modified policy."43

In this sense, the model of rational purpose is also a rational model of public learning, outlining a systematic procedure for formulating, implementing and modifying public policy. The central government (this could be the national government or the state) is viewed as the appropriate vehicle for analyzing problems, discovering policy solutions, developing guidelines for policy implementation, instructing localities on implementation, evaluating

42. Id. at 13-14.

43. Id. at 16 . 
program results, and modifying the policy or implementation procedures in order to achieve desired results. In essence, the central government both learns for society and teaches localities how to solve problems.

This approach to policy formulation and implementation is exemplified by the land use and growth management policies adopted in many states. For example, in most states that have enacted land use legislation, there has generally been some type of environmental crisis resulting in state intervention into the traditional local land use control and regulatory system (e.g., a drought in Florida, environmental degradation caused by second-home development in Vermont, degradation of sensitive coastal areas in California, rapid population growth and sprawl in the mountains and ski areas of Colorado). In these states "the land use problem" has been defined as the inability of local land use decision making bodies to deal effectively with environmental decisions that have greater than local impacts. Inherent in this definition is a solution which implies that centralized state control of certain land use decisions is necessary. ${ }^{44}$ Centralized state control usually takes the form of state government establishing policies as to the types of development or geographic areas that are of state-wide significance, setting guidelines for the implementation of these policies, identifying areas for use of guidelines and then directing localities to plan and regulate land use accordingly. The state often provides funds for local implementation and maintains the option of overruling local decisions if they are not consistent with state policy. This process is an example of the central-peripheral model of policy formulation and implementation.

In contrast, the Massachusetts Growth Policy Development Act focuses not only upon solving existing land use and growth management problems, but upon developing a continuing process by which these problems can be examined and new answers can be found. The Act attempts to initiate an inductive rather than a rational model of public learning.

The differences between the rational and inductive models of public learning center around four sets of assumptions: (1) assumptions concerning the manner in which public problems are defined and demand public action; (2) assumptions concerning the manner in which public learning occurs; (3) assumptions about the manner in which this learning is translated into action; and (4) assumptions about the importance of a process orientation.

First, the inductive model differs from the rational model in that it does

44. Centralized state control does not necessarily mean centralized state administration of land use and growth management decisions. Indeed, in some states, regional bodies have been established to administer state-created guidelines. It is possible to use substate regional bodies to "decentralize" state land use decision making or to draw the local public into the decision making process. In Vermont and California substate regional bodies vary in their interpretation of statemandated guidelines and in their definition of area-wide needs. In most instances, the criteria for defining issues of more than local concern or areas of critical impact did not include local participation. It is our contention that Massachusetts is the only state to reject the "central-peripheral approach" to land use policy making. 
not take the definition of public problems as given. It assumes that the nature of public problems is constantly shifting. Thus, it is assumed that by the time policy is designed to deal with a perceived "crisis situation" the conditions which previously defined that crisis will have changed to such an extent that the initial problem definition will no longer be appropriate. The inductive model also assumes that the public definition of a problem is often a function of a variety of alternative definitions held by different officials and interest groups. That is, different groups have different values and consequently define problems differently. Further, the inductive model assumes that the manner in which a problem is defined has a substantial impact upon the policies designed to ameliorate it. For these reasons, the inductive model focuses more attention upon the process by which public problems are defined than does the rational model. ${ }^{45}$ The inductive model stresses the need to transform problem definitions to meet changing conditions in the physical and social environment.

The second difference between the rational and inductive models relates to the manner in which "learning" is assumed to occur. The rational model assumes that the objective analysis of a specific problem will lead to a set of alternative policy solutions that must be examined on the basis of their comparative costs and benefits and political acceptability, etc. The alternative solution deemed to be the most cost-effective and which reflects the concerns of a significant number of politically important interest groups is then selected, placed in legislative or administrative format and, implemented. Allowing for a certain period of implementation, the policy is evaluated and modified to correct unanticipated results. Learning is hypothesized to occur through objective analysis of specific problems and policies. Through this analysis, technical solutions are derived, implemented, and evaluated; governmental agencies are viewed as learning through this process.

In contrast, the inductive model hypothesizes that learning occurs when individuals or organizations are confronted with dilemmas or inconsistencies between the outcomes of their actions and their values (that is, their espoused intent). Learning occurs during explicit analysis of the values which infuse certain problem definitions, policies, or actions. This explicit analysis forces individuals and organizations to confront conflicts between their values and the specific outcomes of their policies or actions. It is assumed that they will respond to this conflict by changing either their values, problem definitions or actions. This change is defined as "learning." Thus, the inductive model attempts to bring conflicts between values, problem definitions, conditions in the environment, and policy outcomes into the spotlight of public scrutiny. It is less concerned than the rational model with the search for technical solu-

45. See D. Schon, Beyond the Stable State, at 116-79 (1971). Schon refers to this as the process of generating "ideas of good currency." 
tions or objective analyses; and more concerned with arriving at problem definitions that consistently link individual and organizational values to the changing conditions in the environment.

The third difference between the rational and inductive models relates to the governmental level at which "learning" is presumed to occur and the manner in which learning is translated into action. The rational model, with its emphasis upon objective analysis and technical solutions, assumes that "central" government units are best equipped to "learn for society" and to translate this learning into action. Central government agencies are viewed as being better able to attract the expertise necessary to analyze and solve public problems, and as having the funds and power necessary to implement selected policies (i.e., the central-peripheral approach to policy formulation and implementation). In contrast, the inductive model assumes that networks involving both private individuals and officials from a variety of governmental levels are necessary to force specific agencies to confront conflicts between their values, problem definitions and policies. In addition, these networks are viewed as the most appropriate vehicles for translating the learning which occurs into action. The inductive model hypothesizes that the central-peripheral approach to policy implementation actually leads to a situation in which localities attempt to sidestep central policy mandates in order to achieve their own local objectives. Consequently, central policy mandates are more often ignored or reformulated to meet local needs rather than implemented in their intended fashion. The inductive model recognizes this situation and attempts to force localities to confront the central policymakers with the undesirable consequences of their policy mandates. Out of this confrontation, it is assumed that policies will be restructured so that they are consistent with both central and local needs. In short, networks are needed which encourage two-way communication between central and peripheral actors rather than the oneway communication implicit in the policy mandates of the rational mode. Such communication patterns are necessary to facilitate the restructuring of policy to meet specific local needs.

The final difference between the rational and inductive models is that the rational model focuses on finding "the correct answer" or policy solution to a specific problem while the inductive model concentrates on developing continuing processes through which problems may be redefined and innovative policies suggested. The rational model emphasizes objective technical analysis to determine appropriate "policy fixes," while the inductive model emphasizes explicit examination of changing values, environmental conditions and problem definitions, and the creation of networks that will facilitate continuing examinations of this type.

The preceding sketch of the differences between the rational and inductive models of public learning helps to highlight the innovative aspects of the Massachusetts Growth Policy Development Act. 


\author{
V \\ Evaluating the Local Impacts \\ of the Growth Policy Development Act
}

A. A Framework for Evaluation

The inductive model of public learning provides a framework for understanding the objectives of the Massachusetts Growth Policy Development Act. These objectives were spelled out earlier in this paper. Essentially, the objectives fall under three headings:

Increasing Citizen Participation in the State Policy-Making Process

- involving citizens in an ongoing dialogue about land use and growth management problems

- creating a state-wide coalition or constituency for better planning

- providing a municipal voice in state policy making

- helping to clarify state priorities

Increasing Local Planning Capabilities

- encouraging citizens and public officials to explicitly analyze their community's past development patterns, the impact of existing policy on these patterns, and the community's major growth management problems and priorities

- increasing dialogue and information sharing among town boards, particularly regarding decisions with land use and growth impacts

Forcing Intergovernmental Collaboration in Growth Management

Planning and Decision-Making

- facilitating information sharing among state, regional and local governmental units

- focusing attention on problems of greater than local concern

- sending a message to the state about the impact of previous and existing state programs (i.e., making state investment and regulatory programs more responsive to local needs through an explicit analysis of their growth impacts)

The integration of these objectives with the assumptions underlying the inductive model of public learning provides thirteen hypotheses that can be used to guide further evaluation of the growth policy process. ${ }^{46}$

1. Discussion within Local Growth Policy Committees leads to new defini-

46. These hypotheses were used to frame the evaluation prepared by L. Susskind \& $M$. Elliott, A Survey of Local Growth Policy Committees and Their Impacts (1977) (working paper published by the MIT Laboratory of Architecture and Planning). 
tions of land use and growth management problems as citizens and local officials explicitly test their assumptions and the values which infuse the community's existing definitions of land use problems.

2. New definitions of land use and growth management problems lead to innovative local policy recommendations, since the manner in which a problem is defined often influences proposed policy responses.

3. Discussions within Local Growth Policy Committees lead to greater consistency in the growth management decisions of town boards, particularly decisions with land use and growth impacts.

4. New problem definitions, innovative policy recommendations, and greater consistency in the decision making of town boards increase local planning and growth management capabilities.

5. Analysis of the Local Growth Policy Statements by Regional Planning Agencies and abutting communities highlights conflicts between existing local policies and their impact upon regional growth patterns and the well-being of surrounding communities.

6. Local review of the regional growth policy reports encourages Regional Planning Agencies to confront the inconsistencies between existing regional programs and local needs.

7. Local Growth Policy Statements encourage various state agencies to confront the inconsistencies between the espoused intent of state programs and the impact of these programs on local growth patterns.

8. Explicit discussion of the differences in state and local perceptions of the impact of existing state programs lead to administrative changes in the implementation of some state programs, and to legislation amending or eliminating programs that are judged to have a negative impact on localities.

9. The Office of State Planning's State Growth Policy Reports and the Wetmore/McKinnon Commission will encourage localities, Regional Planning Agencies, and various state agencies to confront the conflicts and dilemmas implicit in existing state, local and regional policies and programs.

10. The dialogue created through public hearings and the exchange of growth policy statements and reports among localities, RPA's, and the state will create new interpersonal networks for state growth policy formulation.

11. The informal networks created by the growth policy process will provide a temporary vehicle for handling specific land use and growth management problems involving local and State conflicts.

12. The communications networks created by the growth policy process will form the foundation for the creation of a state-wide constituency for better planning. 
13. Residual informal networks formed in the growth policy process will be used to address the issues raised by the process.

These hypotheses illustrate that the primary purpose of the Massachusetts Growth Policy Development Act was to establish a new state-wide planning and policy formulation process. The process emphasizes individual and institutional learning through explicit analysis of both the definition of the State's growth management problems and the conflicts and dilemmas inherent in existing state, local and regional policies. The Act sets the stage for formation of communication networks which will facilitate the redefinition of growth management problems.

In essence, the Growth Policy Act represents an agreement between the members of the Local Growth Policy Committees, state, regional, and local officials to engage in a learning process that does not embody a clear cut conception of what the end results will be. It is a creative rather than a reactive approach to both citizen participation and public learning. The state government has not proposed a set of policy solutions to the Commonwealth's growth management problems and asked citizens and local officials to react. Instead, state government has invited citizens and governmental officials to engage in public exploration of these problems. In the long run, the success or failure of the Massachusetts Growth Policy Development Act will be determined by the commitment of citizens and officials to this critical self analysis of the manner in which their values and assumptions influence existing growth policies, by the ability of the communications network to pinpoint inconsistencies between programs and their intended results, and by the creation of interpersonal networks which confront governmental agencies concerning these inconsistencies and prod them to develop new problem definitions and policy responses.

\section{B. Research Strategy}

To test our hypotheses about learning at the local level, we surveyed (by telephone) the heads of 103 Local Growth Policy Committees (LGPCs). We stratified our LGPC selection. Four criteria were used in our sample: region within the state, the level of LGPC activity, community size, and community character (urban, suburban, or rural). The results of the telephone survey allowed us to develop an initial typology of LGPCs and their impacts. Table I indicates the extent to which our 38 percent sample was representative of the 324 LGPCs that were ultimately formed statewide. A series of in-depth case studies with all or most of the members of twelve LGPCs verified our initial findings. ${ }^{47}$

47. Our case study communities included one large city, seven medium sized cities and towns, and four small towns. Eight were in the eastern part of the state, two in the central part and two in the west. Five had highly successful LGPCs, three were moderately successful, and four were 
TABLE I

LGPCs InCluded in the Telephone Survey*

LGPCs not formed (cities and towns that chose not to participate)

LGPCs formed (as of August 1, 1976)

Held only onc hearing

Held two hearings, but produced no Statement

Submitted a tentative Statement

Submitted a final Statement

$\begin{array}{ccc}\begin{array}{c}\text { number } \\ \text { actual } \\ \text { number }\end{array} & \begin{array}{c}\text { included } \\ \text { telephone } \\ \text { survey }\end{array} & \begin{array}{c}\text { percent } \\ \text { included } \\ \text { in telephone } \\ \text { survey }\end{array} \\ 27 & 0 & 0 \\ 324 & 103 & 32 \% \\ 71 & 9 & 13 \% \\ 95 & & 46 \% \\ 19 & 44 & 37 \% \\ 105 & 7 & 46 \%\end{array}$

* This Table refers to the situation as of August 1, 1976. By July 1977, 330 LGPCs were formed; 300 submitted Growth Policy Statements.

The telephone interviews were elaborate. We elicited comments about: the LGPC membership, the members' attitudes toward the Growth Policy Development Act and state government, examples of learning that occurred within the Committee, the nature of the Committee's dialogue, the predicted future of the LGPC, and the anticipated outcomes of the LGPC's work and the effects of the regional planning agencies and OSP. Each interview lasted an average of one hour.

We were interested in the extent to which twelve preselected factors had an impact on LGPC community policy, local attitudes, and the views of LGPC participants. Seven of the preselected factors focused on the character of the community:

1. location within the state;

2. educational level;

3. population size;

4. urban, suburban, or rural character of the community;

5. the extent to which land use and growth management issues were of concern to the community prior to LGPC formation;

6. the degree of planning sophistication the community brought to growth policy discussions;

7. the history of citizen involvement in local government and civic affairs.

We gathered most of this information from Local Growth Policy Statements, telephone interviews, and other sources such as local newspapers and the town monograph series published by the State government.

unsuccessful. For detailed case study reports, see I. Greenberg, The Massachusetts Growth Policy Development Act: Barriers to Public Learning (Oct. 1977) and S. Yaffee, Municipal Involvement in the formulation of State Growth Policy: The Implications of Traditional Local Planning Practice (Oct. 1977) (working papers published by the MIT Laboratory of Architecture and Planning). 
We supposed that five other factors might explain the success of LGPCs. These factors related to the Committee members themselves:

6. the ability of the Committee leaders to promote open discussion of alternative viewpoints;

7. local attitudes toward State government;

8. local attitudes toward existing regional planning agencies;

9. participants' attitudes toward the growth policy development process;

10. the representation and active participation of conflicting interests on the LGPC.

This information came from the telephone interviews, Local Growth Policy Statements, minutes of LGPC meetings, and from staff members in the Office of State Planning who provided technical assistance to LGPCs.

We surmised that the community and committee characteristics would help explain the extent to which LGPCs were successful in promoting public learning and in realizing the Growth Policy Development Act objectives. We looked for three outcomes using eight indicators of success. Our information about the work of the LGPCs came primarily from the heads of the committees themselves. We assembled information that could be cross-checked by reading local responses to the OSP questionnaire before conducting the telephone interviews and by asking for examples, illustrations, names, and dates from the interviewees. The survey findings held true for our twelve on-site case studies confirming the validity of the telephone interviews.

\section{Findings}

Our interviews and case studies suggest a four-part ranking of LGPCs and their impact:

Type I Communities: Substantial Individual Learning and Substantial Public Learning. Noticeable impact on attitudes toward local growth policies, local institutions for planning, attitudes of LGPC members, and communitywide perceptions of growth priorities.

Type II Communities: Moderate Individual Learning and Occasional Public Learning. Changes in the attitudes of most LGPC members and some impact on public attitudes toward local growth policies.

Type III Communities: Marginal Impact. Slight changes in the attitudes of LGPC members and slight impact on public perceptions of growth policy issues. No impact on the objectives of local growth policies or proposed changes in the design of local institutions for planning.

Type IV Communities: No Impact. No change in attitudes of LGPC members. No impact on public perceptions of growth policy issues. No impact on the 
objectives of local growth policies or proposed changes in the design of local institutions for planning.

Our sample revealed 13 Type I communities (13\%), 59 Type II communities (57\%), 19 Type III communities (18\%), and 12 Type IV communities (12\%). This probably underestimates the number of Type IV communities in the state, since we only included cities and towns in our sample that had established a Growth Policy Committee by August 1, 1976. Eight percent (8\%) of all cities and towns in the state, 27 out of 351, did not choose to create LGPCs.

The Growth Policy Act was most successful in communities which shared several antecedent characteristics: most were unsophisticated in land use planning, had traditions of public participation in local decision making, and local growth policy issues were of some concern prior to the passage of the Act. In successful communities LGPCs tended to have strong committee leadership. Members were, for the most part, positively disposed to the Act's objectives. While suspicion of state government is almost universal among Massachusetts localities, successful LGPCs seemed less negative toward the state than the "unsuccessful" cities and towns. Finally, most of the successful committees represented a broad range of local interests.

These findings confirm some of the propositions posed by the advocates of public learning. They suggest that strong group leaders are necessary for community participants to confront their differences and to develop local policy consensus. An obvious corollary is that a fair cross section of interests must be represented if public learning is to occur. The odds of success are greater if the process of inquiry occurs in a positive atmosphere in which trust is possible. The process was successful only in communities that were willing to accept the possibility of a local advantage or the State's good intentions.

In communities where the Growth Policy Act was unsuccessful, hostility toward the State was so great that it undermined the participatory effort. These cities and towns were very negative about the entire growth policy development process. They had less impressive records, on average, with regard to past attempts to ensure public participation in local decision riaking. LGPC heads in less successful localities did not focus debate on value differences within the LGPC or within their community. Nor did LGPCs in the least successful communities see themselves in an educative role. They made little effort to reach out for public participation.

\section{Type I Communities}

The Massachusetts Growth Policy Development Act served as an effective catalyst to the re-evaluation of local land use and growth policy in Type I communities. As a result of the LGPC efforts in Type I communities, master 
planning processes were altered, zoning code modifications and new growth management techniques were proposed, responsibilities assigned to local boards were shifted, citizen watchdog groups were established, and efforts were initiated to increase citizen involvement in local growth policy decisions. In short, Type I communities moved beyond an examination of existing growth policies toward proposed reforms in local planning institutions and adoption of modified growth policies. Most Type I communities experienced substantial growth pressures. In several towns, the recognition of serious growth pressures helped to develop a local interest in and support for the work of LGPCs. Although growth issues existed in these communities, a sense of crisis did not. At least seven and possibly ten Type I communities were not as far along in coping with these problems as they were when the LGPCs completed their work.

Nine of the eleven nonurban Type I communities showed significant increases in concern for the rapid formulation of effective planning institutions. The remaining two are actively engaged in planning. Six communities are altering the flow of information between local boards and reorganizing local policy making procedures. Ten LGPCs remain intact, providing new vehicles for coordinating local growth management efforts. The other two Type I communities are engaged in placing LGPC members on other municipal boards. Type I cities' and towns' efforts to promote open and direct discussion created a successful learning environment. New information was assembled and existing information codified. Confrontation of groups with conflicting values and goals spurred considerable attitude change.

Most local officials in Type I communities perceived the growth policy development process as a useful opportunity for local review. They supported the work of LGPCs (although they were not necessarily enthusiastic about the state's role in the effort). They were serious about selecting committee members who would represent a cross section of municipal interests. Without exception, LGPC discussion leaders in Type I communities were dynamic, respected and effective. Some communities specifically sought out individuals known for their leadership abilities. In other municipalities, highly concerned, active individuals chaired the LGPCs because of their interest in the process. In all but four cases, these leaders were active on local boards or had been in the past. In some cases this reinforced traditional views about local growth policy, but in most of the cases the chairperson served more as a facilitator than a director. The important role of the LGPC selection process and the leadership capabilities of the Committee head in the success of Type I LGPCs should not be underemphasized.

Several highly educated, small suburban towns near large urban centers had successful LGPCs, but these demographic characteristics did not always correlate with success. Communities of this sort tend to have more positive at- 
titudes toward citizen participation, are more prone to experimentation, and are more amenable to land use planning and growth management. Thus, the residents are likely to support a LGPC if it initiates positive actions and open discussions. In the final analysis, it is the Committee's ability to generate discussion and resourcefulness in initiating action following its conclusions that account for local reactions.

In addition to the importance of the LGPC member selection process, the role of group leaders, the overall support of local officials, and the resourcefulness of the LGPC itself; we explored the possibility that the LGPC size and the tradition of public participation in local affairs might explain the success of Type I communities. The size of the LGPC was largely unimportant (although successful committees tended to have somewhat larger than average memberships). Traditions of public participation in local decision making correlated with the success of Type I communities.

LGPC attitudes toward state government and regional planning agencies had little impact. The committees were self-directed and did not rely on other levels of government. Attitudes toward the state government ranged from "deep suspicion," "cynicism," "an acceptance of the state's intentions at face value," to "it is about time [we had] an opportunity to express our view to the state."

Type I communities provided most of the information requested by the Office of State Planning, but saw this as a secondary function; important only if OSP followed up effectively and impartially in preparing its recommendations. Thus, the credibility of OSP was irrelevant to the initial success of Type I communities.

Finally, special efforts to increase citizen participation in framing the Local Growth Policy Statement explain, in part, the success of Type I LGPCs. Given the difficulty of mounting public hearings on long-range, nonspecific issues, the turnout for LGPC public hearings in Type I communities was quite good. All but three communities had more than 35 people at their first and second hearings. This was accomplished by advertising at polling places, town meetings or in newspapers. Some sent flyers with questionnaires home with school children and generated newspaper coverage of local growth policy issues; others took full-page ads, and one community prepared a montage of twenty possible future headlines on future growth to be discussed at the public hearing. Communities used smaller precinct meetings in large communities; emphasized personal discussions with friends and neighbors; and promoted direct contact with Leagues of Women Voters, citizen advisory committees, business associations, and fraternal organizations.

The extent of citizen involvement was as dependent upon the willingness of the committee to work at getting the public involved as it was on the presence of local issues of major concern. In return, citizen involvement rein- 
forced the LGPCs' work. The LGPCs' credibility was enhanced and local consensus on growth management issues was solidified by making local policies explicit.

\section{E. Type II Communities}

In many cities and towns the LGPCs' work did not lead to immediate changes in local policy or proposed changes in the structure of planning operations. However, the probability of such changes occurring in the future increased as more and more residents became actively involved in growth management decisions and as the local agenda of land use planning issues was sharpened through debate and discussion. Thus, the politicization of LGPC members and the opening up of local growth policy debates are signs that the growth policy development process was successful. If individual choices are reconsidered, if different interests confront the variations in their beliefs, the seeds of reform are sown. Fifty-nine of the communities surveyed experienced moderate shifts in community attitudes toward growth policy questions or obvious examples of individual learning. We have labelled these Type II communities. Ten were almost at the point of enacting community-wide policy shifts. Twenty-three exhibited signs of public learning (e.g., reconsideration of prevailing policies, reformulation of local growth management objectives, rethinking of planning responsibilities). Twenty-six displayed substantial individual learning, but no impact on the larger community.

LGPCs in Type II communities were not willing to push for changes themselves, but sought to motivate existing boards. They accepted the existing institutional structure for planning; only a couple of committees expected to remain intact when the OSP responses were finalized. They sought to define and clarify local policy rather than change it. They viewed themselves as information and communication sources rather than as originators of policy. LGPC members in Type II communities gained a new sense of community identity and, in some cases, solidified antistate feelings. Values were not confronted as quickly as in Type I communities. Many committees kept discussions general to avoid disagreement over particulars. The most positive outcomes in these communities were the almost universal increase in concern about growth policy decisions, a large increase in knowledge about how planning is done, and an increased sensitivity to how vulnerable most communities are to shifting growth patterns and pressures. For some LGPCs, this amounted to the town planners on the committee "educating" the citizens. For others, it represented an exploration of community issues by individuals previously involved with only their special interests.

Type II communities have relatively little in common. Of the eleven mainland Massachusetts regions studied, there were nine in the Type II group. Population ranged from 600 to 176,000 . Educational levels were equally divergent. Most were smaller towns, located beyond the direct influence of met- 
ropolitan areas and faced with 25 percent growth rates over the last ten to fifteen years.

An analysis of growth policy options requires an evaluation of values and presuppositions, a vastly expanded increase in knowledge about past trends and current opportunities, and a willingness to do a considerable amount of work. Like most groups, some LGPCs were unable to achieve these conditions because:

1. a great deal of information was presumed to be commonly shared or professionally held (thus, the presentation of such information did not provoke any reevaluation);

2. members had a stake in neutralizing disagreement to avoid adverse effects on social or political positions;

3. individuals had interacted with each other before and reinforced each other's views;

4. members were busy with other responsibilities, not interested or motivated;

5. the committee was not positively reinforced by highly motivated members or by outside influences; or

6. the committee perceived its role to be futile because the local or state system seemed too set in its ways, their task seemed too complicated, or there was no understanding of local or state growth issues. ${ }^{48}$

Type II communities experienced little change in local growth policies and minimal pressure for the reform of local planning institutions as a result of the LGPCs' work. Town-wide attention to local growth issues increased, local growth priorities were made more explicit, and the extent of public participation in considering local growth policy expanded. Many individual LGPC members in Type II communities learned about the local land use choices at stake. Many participants shifted their views about what should happen locally or regionally. LGPCs in these communities made no conscious effort to reformulate local growth policies or to translate what they learned into proposed reforms of local planning institutions. Had these communities adopted such objectives, they might have achieved them. Instead, they concentrated on documenting local attitudes and completing the OSP questionnaire.

\section{F. Type III Communities}

Not every LGPC in Massachusetts considered the growth policy development process a useful local exercise. Nineteen committees decided the process was unnecessary for their locality, although they acknowledged the possibility

48. I. GReEnberc, supra note 47. 
that their reports might produce some benefits at the regional or state levels. All but three Type III communities considered their ongoing planning activities superior to the level of effort implied by the OSP questionnaire. Others thought they had no growth management problems whatsoever and felt that they were beyond the self-examination level advocated by the Act. Several are highly educated, college-oriented towns. Most have proficient planning staffs, have established citizen goals and policy committees before, and populated the LGPC with individuals experienced in local planning. We were not surprised when the conclusions and recommendations of these LGPCs mirrored existing patterns of thought in these communities. What is surprising is that some of the most successful Type I LGPCs were in towns with similar characteristics (e.g., higher-than-average educational levels, relatively high importance attached to growth policy issues or growth pressures, wide range in population size).

Type III communities participated reluctantly. Statements such as "The town is simply tired of worrying about land use issues," and "It's a massive effort for volunteers to define our goals and support the necessity of their restrictiveness without appearing overly selfish," were coupled with a predominantly negative attitude in most of these towns toward the state government. The OSP questionnaire, a long and elaborate information gathering tool, affirmed the sense that many Type III communities had of state incompetency. The idea that the state government might be committed to public learning exceeded what most Type III localities were willing to believe.

LGPCs in Type III communities had no impact on local growth policies and promoted little reconsideration of the design of local planning mechanisms. There were a few instances in which local growth priorities were stated more explicitly as the result of the LGPC's efforts. Little individual learning took place.

\section{G. Type IV Communities}

Twelve communities simply did not learn anything by participating in the growth policy development process. Most were negative about the process itself and did not participate actively. Most Type IV communities are small towns from the western part of the state or from Cape Cod. They have strong feelings about their uniqueness and the state's insensitivity to nonurban needs. The remaining two urban regional centers and two suburban centers are close to Boston and have had negative experiences with the State or the city of Boston. As "one more State program," the Growth Policy Development Act was the target of long-standing hostility.

Complaints from this group (as well as from some communities in the other three categories) included:

1. The OSP Questionnaire. OSP, as required by the Act, sent each commu- 
nity a 95-question, 20-page questionnaire. The format included both multiple-choice and essay questions. More than 70 percent of the communities found fault with the form and style of the questions. They complained about the complexity of the terminology and what appeared to be a bias in favor of regionalism. Many LGPC members found the questionnaire tedious and boring, which adversely affected committee discipline and morale. Some LGPC members felt that the first part of the questionnaire, which asked about each town's history, was too long and kept people from the controversial and interesting issues relative to the town's present and future. There was confusion about whether the LGPCs were expected to thrash out each item until achieving consensus or merely to note different points of view. Many LGPCs adopted methods to limit discussion on each question by setting time limits (usually 15 minutes) or letting subcommittees or individuals answer them. In spite of instructions to the contrary, many communities felt that they needed professional advice and technical consultants to answer the questionnaire. The questionnaire asked for opinions and attitudes, but people felt compelled to include massive amounts of factual data. The language was considered too complex by some, too vague by others. Committees feared being trapped into making vague statements that might be misinterpreted by state officials.

LGPCs in rural areas thought the questionnaire was too urban oriented, that large parts were inappropriate, and that important issues like schools were ignored. Some of these committees also felt that the highly structured nature of the questionnaire produced a "stacked deck for regionalization," that it was "written with the assumption that towns do not know what's going on," and that a "more fluid, less restrictive format" would have been more conducive to independent thought.

2. Required Hearings. The required hearings came under considerable fire. Relatively few communities in the Commonwealth had successful citizen input. Average attendance for hearings was less than fifteen. The fault was attributed partly to the lack of funds (to mount a survey or other outreach efforts), but most of the blame was attributed to citizen apathy and the unspecific nature of the growth issues under discussion. Although some communities felt that we "should get as much input as we can from citizens, since they have to live with the outcomes," it was also suggested that many residents are "selfish and parochial" and do not take the larger view, and that hearings are "not good for generating ideas, they are only good for reacting-usually negatively-to solid issues." Over thiry LGPC heads commented on what they perceived to be the impersonality of the process and lack of concern for local priorities in spite of the fact that the thrust of the Act was to secure local input into the formulation of state policy.

3. Technical Support. Some committees felt isolated and lacking the technical support they believed was required. Conferences and workshops held at Tufts University and MIT to explain the purposes of the Act and to help ori- 
ent LGPC members were thought of highly, but left many attendees with doubts as to the state's intentions. ${ }^{49}$

4. Timetable. Most communities-Type IV in particular-complained that the timetable for completing the questionnaire was too short. The schedule for completing local Statements continued into the summer, conflicting with vacations. It overlapped with town meetings and local elections in many places, taxing the time of the most active residents. It was "too short a period to develop a sense of achievement or to accomplish things." Support materials arrived late. These included the announcement of the law, the OSP handbook, the OSP Questionnaire, and (environmental, agricultural, and coastal) supplementary questionnaires which were added at the last minute (and largely ignored by the localities). The OSP faced a tight schedule. In retrospect it appears that more time should have been spent preparing the process and putting it in motion. Several LGPC heads indicated that if something positive does come from the Act, it should be tried again because "skepticism would be removed and would do a better job. . . . Citizen participation depends on the results of the process being used and people expecting this beforehand."

5. Appointment of LGPC Members. The LGPC appointment process was questioned by some cities and towns. A few committees felt that selection "by the powers that be" biased their particular committees towards either business or conservation interests. Others felt that "volunteer government officials [could] not be the most productive members of these groups due to other commitments, other citizens must therefore carry the weight;" "more effort was needed as to who was selected and why; the group dynamics as a product of the personalities of the individual[s] and the need for an ideal chairperson needs more careful consideration." All in all, Type IV communities found numerous reasons for not participating in the growth policy development process.

\section{VI}

\section{The Impact of the Growth Policy Development Act} on State Land Use Policy

The Growth Policy Act was notable in several respects. Massachusetts chose not to follow the route selected by other states which have presumed that it is the responsibility of the executive branch to present a "master land use plan" or an overarching growth management program to the localities and regions (a "top down" approach). Massachusetts began without the assumption, now widely attributed to the American Law Institute, that effective

49. Both universities secured foundation grants to mount day-long workshops for LGPC members. Office of State Planning staff, legislative committee members, and faculty members of various departments helped explain the intent of the Act and worked to teach leadership skills that LGPC members would need to function effectively. 
growth management requires state government to overrule local land use controls to ensure that developments are planned properly concerning more than local impact or critical environmental areas. Massachusetts began with the novel assumption that widespread public involvement in the formulation of state growth policy was feasible. Some states have distributed surveys to a sample of residents as a means of "involving" citizens in the formulation of state growth policy, but Massachusetts mounted an elaborate process of direct public participation. Finally, the proponents of the Massachusetts Growth Policy Act presumed that it would be necessary to promote extensive public learning to build a constituency that could work for the implementation of the recommendations produced by the process. The creation of Local Growth Policy Committees and the process of direct involvement were designed to put land use and growth management issues on the local and regional agenda, to bring groups with divergent views together to discuss competing growth management objectives, and to deepen public awareness of the likely impacts of prevailing growth management assumptions. Proponents of the Act felt that local officials needed a more formal means of testing their presumptions about what residents are actually thinking, that regional agencies needed better ways of learning what localities actually want, and that the executive and legislative branches of state government need more effective and sensitive techniques for learning about the growth management concerns of localities and regions.

Of the 351 cities and towns in Massachusetts, 324 participated in the growth policy development process. Over 6,000 residents served as members of Local Growth Policy Committees; thousands more were involved in various local and regional hearings. For the 85 percent of the cities and towns that established Growth Policy Committees and prepared Local Growth Policy Statements, the process proved to be extremely valuable, at least at the local level. ${ }^{50}$ In these communities, local growth policies are more explicit, more residents understand the implications of current growth management policies, boards and departments understand the need for common goals and the dangers of working at cross-purposes, action agenda have been fashioned, and individuals who did not participate in local affairs have been drawn directly into municipal government work.

While the thirteen regional planning agencies were not equally active or successful, the Metropolitan Area Planning Council (MAPC) (including 101 cities and towns and over half the population of the state) made a major attempt to fulfill its mandated responsibilities under the Act and tied its work on the growth policy process to ongoing efforts to involve member communities in the preparation of a regional land use plan. Thus, many localities and some of the regional planning agencies not only completed their assigned

50. L. Susskind \& M. Elliott, supra note 46 , at 44. 
parts in the process, but benefitted substantially. All the participants waited to see whether or not the primary objective of the Growth Policy Act-the shaping of a state growth policy responsive to local and regional concerns-could and would be achieved. The Office of State Planning published its summary report, City and Town Centers: A Program for Growth, in October 1977.

\section{A. The OSP Report}

The OSP report consisted of five parts:

1. an overview of local perspeçtives on growth management;

2. a region-by-region review of area-wide growth management concerns and priorities;

3. a summary of state perspectives on growth (taken from two previously published OSP reports);

4. an analysis of the points of agreement and disagreement revealed in the first three chapters; and

5. an outline of specific policy and action recommendations.

Part 3 indicated that cities and towns are concerned about preserving their physical character (vistas, historic buildings, traditional town centers, open spaces); their social and cultural character (closely-knit neighborhoods, shared values, community pride); and the political or governmental organization with which they are accustomed (strong home rule, reliance on the town meeting form of government, dependence on part-time, local, volunteer officials, a high degree of citizen participation). According to Local Growth Policy Committees, threats to community character include: rapid and illcommodated growth, environmental degradation, loss of agricultural activities, suburbanization of outlying areas and urbanization of inner suburbs, loss of open space and historic assets, deterioration of traditional town centers, poorly planned commercial developments, and state or federal intrusion into local affairs. Ideas for preserving or enhancing community character, taken from Local Growth Policy Statements, include: ensuring that state statutes and regulations are sensitive to community differences, improving the administration of the state's existing environmental laws and regulations, ensuring the preservation of agricultural land, increasing the level of funding for open space acquisition, neighborhood improvements and downtown revitalization, providing adequate funding for state mandated programs, improving and expanding enabling statutes requiring that local governments be consulted whenever a state action or investment will affect them, and improving or expanding technical assistance to cities and towns.

A further review of local concerns about issues such as economic development, housing and residential growth, taxation, growth-related facilities, 
transportation, wastewater treatment, water supply, solid waste management, recreation, and growth management seems sensitive to long-term local complaints that the state government has failed to acknowledge. The suggestions culled from the Local Growth Policy Statements concerning economic development include: improving the management of the state's regulatory process by streamlining permit and licensing procedures; aggressively attracting federal public works programs; revitalizing downtown business areas; providing the public facilities necessary to attract industry; improving manpower training programs to meet the needs of new industries for skilled labor; and expanding small business assistance programs. With regard to housing new residential growth, OSP identified the following dominant local concerns: the need for a wider range of affordable housing opportunities; the need for more equitable distribution of low and moderate income housing among communities; and the need to ensure that future residential growth is equal to the community's ability to absorb it.

According to the OSP, the single most important lesson drawn from the growth policy process is that "state and local fiscal relations are not what they ought to be."

Nearly all the communities describe the present system of state and local taxation as regressive and a deterrent to economic development, the overall level of taxation as excessive, and personal property tax payments as both onerous and burdensome.

In further discussions of fiscal problems, cities and towns pointed to inadequate and inequitable state aid to communities, unreasonable assessments on communities (such as the costs of county governments), unnecessarily high levels of state and local public spending, school committee autonomy, rapid growth outstripping the local capacity to accommodate it, newer residents with higher expectations about public service levels, 100 percent valuation and its implications for residential neighborhoods, and state level bureaucratic mismanagement. This list will not seem fresh to Massachusetts residents who have tried to register these views with the legislature and the chief executive for years, but its inclusion in a state report endorsed by the Governor represents an important step forward. Progress can be made toward solutions when the agenda of problems and priority concerns is agreed upon.

The OSP Report recounted the concerns and ideas expressed by Local Growth Policy Committees in regard to transportation (increased non-local funding for public transportation, an end to major new highway construction projects, reform of the MBTA assessment formula, an increase in the flexibility of Chapter 90 administration, revitalization of commuter and freight rail service), wastewater treatment (relax state water quality standards for smaller communities), water supply (provide more stringent protection for existing water supplies, require state agencies such as the Department of Environmen- 
tal Quality Engineering to be more sensitive to community character and differences, give a higher priority to water quality concerns), solid waste management (make state standards and regulations more sensitive to the fiscal limitations on local government), recreation (increase non-local funding for open space, provide state payments in lieu of taxes for communities affected by state recreation investments, allow communities a larger part in decision making about state park and forest management), and growth management (modernize or eliminate county government, promote intermunicipal planning in areas such as solid waste management and maintenance of water supplies, improve the effectiveness of regional planning agencies, enable communities to enact design review for a new commercial, industrial and apartment development).

In an effort to summarize what was learned about attitudes toward residential and industrial growth, the OSP tabulated Local Statements about the "most desired future." The tabulations appear below.

Desired Future Residential Growth

Higher growth than in the recent past

About the same growth as in the recent past

Slower growth than in the recent past

No growth (including those communities that

do not expect to grow)

Hard to say, not indicated, did not participate in growth policy process 
actively seeking an increased level of industrial growth. Other communities, having had what they consider to be favorable experiences with industrial growth also desire further industrial growth, as do those that seek to expand or fill their industrial parks. Those communities in predominantly rural or environmentally sensitive areas generally oppose further industrial growth.

The OSP review of local perspectives on growth is faithful to the concerns expressed locally. The chapter on Regional Growth Perspectives continued in a similar vein. The issues discussed include: housing and residential growth, industrial development, center revitalization, transportation, and environmental protection. An extensive region-by-region review provides sensitive readings of the differences among the various sections of the state. All too often, residents in the western and southeast portions of Massachusetts have found that legislative and administrative actions taken in Boston reflect a narrow and inappropriate definition of their needs. If the sensitivity to regional differences apparent in the OSP Report begins to permeate thinking and action at the state level, the growth policy process will have been successful.

While the OSP Report talks about building stronger regional institutions, it carefully points out that it would be desirable to do so in a way that does not force collaboration on cities and towns that do not want to participate. Again, the dominant local view (skepticism and perhaps disappointment with the ineffectiveness of existing regional planning agencies) seems to have percolated up to the state level. The Report describes "service delivery breakthroughs" at the regional level, suggesting that the state's view of stronger or better regionalization might be managed more effectively on an area-wide basis. OSP claims that rural areas are more likely to accept the idea of regionalization since they are quicker to acknowledge their own administrative limitations. This may be a questionable reading of the Regional Reports, but the OSP observation that the larger cities (especially Boston) feel that the existing regional boundaries are too extensive is correct. Unfortunately, no criteria are offered for drawing more appropriate boundaries.

The chapter summarizing the state's view of growth management priorities states the key ideas used in recent years to guide state investment and regulatory strategies. This chapter was a summary of two earlier OSP position papers. ${ }^{51}$ The emphasis was on the location and quality of growth (a focus on center cities and revitalization of developed areas), the level of growth (with respect to economic development, energy policy, capital formation, and transportation), and the role of government in stimulating and channeling growth. Criticisms $^{52}$ of this chapter have centered on OSP's concern with location

51. Office of State Planning, Towards a Growth Policy for Massachusetrs (October 1975); Office of State Planning, An Economic Development Program for Massachusetts (August 1976).

52. Office of State Planning, Towards a Growth Policy for Massachusetts: A Selection of Responses and Criticisms (May 1976). 
rather than the overall growth level; with the failure to distinguish among older centers (some do not have the capacity to absorb new growth at a reasonable cost); with fuzziness about the connection between public and private investments; and with unwillingness to consider rejuvenation alternatives in older centers as support for emerging satellite centers. The main complaints came from suburban and rural communities who charged that an exclusive focus on inner-city revitalization was narrow and would undermine ongoing efforts to manage growth effectively outside the cities. Environmentalists challenged the Office of State Planning's pro-growth orientation, while the business community charged that OSP had not indicated a real commitment to reducing the regulatory burdens on the development industry.

Earlier OSP positions resemble many of the positions contained in City and Town Centers: A Program for Growth. In this work the OSP reformulated and tied many of its policy proposals to Local Growth Policy Committee sentiments and the concerns of Regional Planning Agencies. Some readers found it difficult to accept OSP's assertion that the desire expressed by many suburban and rural communities to slow or stop growth ought to be interpreted as support for the state's affirmative efforts to channel growth into older urban centers. The two views are not necessarily inconsistent but support for the former does not imply a vote for the latter. Indeed, many suburban and rural areas feel they are unable to accommodate additional development, but insist that they have a legitimate claim to state resources for managing the impact of the growth they have experienced. Consequently, such communities argue the OSP's policy of directing state investment into older centers fails to address their needs. The OSP, on the other hand, contended that the Local Growth Policy Statements demonstrated statewide support for many of their earlier positions.

The fourth chapter of the OSP Report highlighted the points on which the three levels of government (local, regional and state) agreed:

1. Economic development should increase;

2. It is important to revitalize city and town centers;

3. It is important to maintain environmental quality;

4. Property tax relief is needed;

5. Farm land should be preserved; and

6. The state must be more sensitive to the differences in community preferences and seek to enhance community character.

The points of disagreement are cited as "choices"; growth versus no growth; public policy versus market forces; regionalism versus home rule; and revenue needs versus tax reform. These are not either-or choices. The OSP's general conclusions were that growth must continue, but that its timing and location should be managed more carefully and sensitively; that public policy 
ought to be used deliberately to shape and constrain market forces; that efforts to impose further regionalization are of little value while efforts to enhance local capacity and to nurture municipal collaboration should be encouraged; and that efforts to reduce the reliance on property taxes should move quickly. The conclusions suggest preferences, but no clear choices, on the major points of disagreement.

An eight-part statement of growth policy objectives was presented in the final chapter. Paraphrased and simplified, the objectives are summarized below:

1. Growth should be channeled in developed areas consistent with local priorities;

2. The quality of future growth and development is important, particularly in terms of protecting environmental, historical, and cultural resources and promoting aesthetically pleasing design;

3. A growth level must be maintained that will provide sufficient jobs and housing for all residents;

4. No community should grow at a rate that will strain its ability to provide the services its residents need;

5. Growth managment processes must be responsive to local needs, timely, and open to public scrutiny;

6. Local controls should not be preempted;

7. Regional variations must be respected; and

8. The State's job is to be responsive to local and regional concerns.

These policies lead to specific action recommendations concerning city and town centers, neighborhoods, buildings, jobs, farms, wetlands, coastlines, scenic rivers, water, growth management, regions, and property tax. The action recommendations were pointed and somewhat risky. Had the report stopped short of specific recommendations, almost everyone could have found something to agree with in the statement of growth policy objectives. The specific recommendations, however, left OSP and the Governor (who played a major role in reviewing and shaping the recommendations) vulnerable.

\section{B. A Summary of the Recommendations}

Some of the recommendations were restatements of proposals that the Governor and his staff had been advocating for some time, although they did represent a reasonable response to the concerns expressed by Local Growth Policy Committees. Many previous proposals were substantially justified for the first time in the problem descriptions provided by the cities and towns. The justified proposals dealt with capital formation, the management of the state's water supply, and strategies for central city revitalization (responding 
directly to local calls for additional state help in underwriting municipal borrowing for local improvement projects), state-aided programs for housing rehabilitation, provision of state funds and technical assistance to encourage self-sufficient water supplies, changes in state codes to encourage rehabilitation of existing structures, and help in expediting the transfer of tax delinquent property to new, more productive uses.

Several of the recommendations grew out of OSP's effort to respond to local cries for assistance. OSP called for passage of a new enabling statute, appended to the existing zoning enabling law, that would allow communities to establish a growth phasing system whereby:

- A local growth program would be organized, reviewed and adopted by the community. The program would be organized by the Local Growth Policy Committee, or a similarly constituted group, reporting through the local planning board. It would be presented to the town meeting or city council for adoption following public hearings.

- The program would include:

(1) an analysis of how much growth the community could reasonably accommodate;

(2) the community's program for public facilities (school, streets, sewer and water) for the coming five-year period; and

(3) a statement of the expected demand for housing growth and proposed local actions to meet that goal.

Reasonable growth would have to be justified on the basis of physical characteristics, existing or proposed public facilities, and historical growth patterns in relation to expected demand.

- The state would assemble and distribute data to be used by communities in preparing their programs and in reviewing their neighbor's programs, including the expected housing demand for each region or subregion of the state. The figures would be revised annually and updated programs would reflect them.

- The program would be reviewed by the state and by neighboring communities. If the program lacked a serious commitment to regional growth demands, the state could mark the program unsatisfactory. The program would go into effect if there were no objections.

- Once in effect, the community could grant a special permit to any housing proposal in order to meet its goal, and could reject proposals once its annual goal had been met.

- Moderately-priced housing would be counted as two housing units toward meeting a community's goal; subsidized housing would count as four. 
- Every two years a participating community would revise its program and submit it for review and approval.

- At local option, a participating community could prepare and adopt a "subsidized housing program" identifying specific initiatives to promote the development of subsidized housing. Once such a program went into effect, potential developers would apply under its provisions, rather than those of that state's anti-snob zoning law (Chapter 774). That is, the community would be effectively exempt from Chapter 774 as long as its own program was in effect.

OSP asserted that the adoption of this measure would be a boon to the Massachusetts construction industry:

The [p]rogram would allow the construction of housing at lower costs, since communities would no longer have to use tools such as large lot zoning and exorbitant street and sidewalk requirements to control local growth. Local Growth Programs would help both home buyers and home builders by:

- allowing all communities to assume a reasonable share of regional housing needs, thereby broadening opportunities;

- avoiding unnecessarily rapid growth, with its incumbent costs for public facilities and services, ultimately passed on to consumers;

- stabilizing or reducing housing costs through the removal of unreasonable requirements;

- reducing construction delays through the use of special permits; and

- providing stronger incentives for the construction of low and moderateincome housing, while allowing communities to initiate their own programs for such housing.

OSP also called for two types of tax sharing: the commitment of a portion of state revenue increases to local property tax assistance and a new program to ensure that property taxes generated by new commercial and industrial development are shared among communities.

\section{Criticisms of the OSP Report}

The structure of the Report and many of the specific policy and action recommendations were similar to existing OSP and gubernatorial positions. This suggested a degree of selective perception. The Report was a political document, not likely to include recommendations inimical to the views of the Governor and his staff. OSP's insistence on hammering away its central city orientation unsettled suburban and rural interests. The predominance of the 
"centers theme" was illustrated clearly by the title of the Report and by the fact that over half of the recommendations related directly to the revitalization of community centers and the rehabilitation of existing structures. OSP supported its emphasis on "centers revitalization" by citing the concern of local growth policy committees about the preservation of community character. OSP maintained that the most consistent theme in the local Statements was that "Massachusetts communities want to preserve their own character, i.e., villages don't want to be suburbs, suburbs don't want to be cities, and cities don't want to be wastelands."

The Report did not address the private sector's complaint that reliance on inefficient regulatory schemes and government interference adds an unreasonable cost to doing business in Massachusetts and forces some business to locate outside the state. In the fall of 1976, the Department of Environmental Quality Engineering was reorganized. A new "permit tracking" process was implemented in an effort to reduce bureaucratic delays for construction projects that would help boost the state's economy. This process; however, fell short of the one-stop-shopping or comprehensive state permit process that many developers had urged. Apparently the OSP chose to ignore this issue. The Executive Office of Environmental Affairs contends that the reorganized permit system is working. Developers claim that more substantial reforms are needed. OSP chose to remain silent, perhaps because they failed to implement a more comprehensive permit-granting procedure in 1976 and partially because it is unclear what type of reform package the development community would have supported. Therefore, it appears that OSP avoided recommending a comprehensive state permit process to avoid conflict within the Dukakis administration.

Another criticism of the OSP Report was its perfunctory treatment of existing regional planning arrangements in Massachusetts. A number of Local Growth Policy Statements criticized the effectiveness of existing Regional Planning Agencies (RPAs). Several communities expressed concern about the appropriateness of existing regional boundaries. In addition, many cities and towns were critical of the manner in which certain RPAs interpreted Local Growth Policy Statements and the quality of the Regional Reports. OSP did not deal with these criticisms and by-passed the opportunity to use the growth policy process as a means of demanding more effective performance from the regional planning agencies.

Finally, the Report suffered from OSP's failure to articulate clearly a position on the state's responsibility for allocating new growth. OSP appeared to be wishing away the adverse effects of the slow growth/no growth policies in effect in many communities. Localities were pleased with the state view that forceful state intervention (fair share allocations) would be inappropriate. The nagging question remains: Who is responsible, if not the state, to protect the 
interests of the poor and disadvantaged when individual communities' efforts to maximize their advantage result in a cumulative effect that no single community meant to create?

\section{Was the OSP Report Responsive to Local Concerns?}

The OSP Report was responsive to the concerns expressed in Local Growth Policy Statements and Regional Reports in several ways. First, the choice of issues and topics discussed in both the first and second chapters of the Report closely followed the descriptions of local and regional growth management concerns submitted to the OSP. While it is true that the OSP distributed questionnaires to Local Growth Policy Committees and formulated guidelines to help the RPAs frame their deliberations, the local and regional priorities identified did not appear to be manipulated (even indirectly) by the state. A number of cities and towns chose to ignore the OSP questionnaire, submitting narratives suited to the ideas they wanted to express.

OSP's sensitivity to regional variations was impressive. State policy has taken such differences into account only when legislation has originated locally and been supported by locally-elected legislators. State-wide policies enacted by the Legislature have not taken regional differences into account. If the future administration of state programs can be tailored to the regional variations identified in the OSP Report, the growth policy process will have been successful.

Many of the action recommendations of the Report were aimed bluntly at sensitizing state agencies to the need for increased administrative flexibility and responsiveness to variations in community priorities. In addition, the OSP called attention to the unintended side effects of certain state programs. If proposed modifications in the administation of Chapter 90 funds, the management of sewer and water programs by the Department of Environmental Quality Engineering, the administration of the state building code, and the operation of Chapter 774 are implemented, these communities that participated in the bottom-up process will be able to justify the time and energy they invested.

The action recommendations enhanced the capacity of local and regional boards to handle their own problems. Few additional restrictions and regulations were proposed. This was responsive to the message that cities and towns conveyed. While reform of county and new metropolitan systems of government may hold the solution to growth management problems in other parts of the country, there is no support for strengthening mid-level jurisdicitons in Massachusetts. Localities must better handle problems of more than local concern or the state will be forced to step in and collaborate. OSP chose the first route in response to local wishes. Now the burden is on the cities and towns to prove that they can handle the responsibility. Finally, OSP proposed 
specific measures to further growth policy objectives of the cities and towns in the Commonwealth. Other states have produced general policy documents, while the Massachusetts OSP generated action recommendations. Proposals for a new system of growth phasing and recommendations regarding tax sharing demonstrated a commitment to the ideals expressed locally, not just a meaningless nod in the direction of local interests.

\section{E. Conclusions}

The OSP Report appeared responsive to the local and regional inputs. From the growth policy process, the OSP and Governor Dukakis learned not only about local and regional priorities, but also about unintended and undesirable effects of past state policies. The OSP's specific action recommendations and the clearly articulated "centers strategy" make it unique in that state reports of this type usually conclude with vague policy recommendations. While the OSP staff may have been guilty of selective perception, almost all the action recommendations were supported by the materials submitted by localities and regional planning agencies.

Within a year of publication, the OSP Report was thoroughly scrutinized at seven public forums throughout the State. Several hundred people attended the Commission-run meetings; over 200 participants submitted formal testimony. Local reaction to the Report and its recommendations are documented in the third interim report of the Special Commission on the Effect of Growth, entitled Implementing the Growth Policy Consensus. ${ }^{53}$ Two things stand out from the public hearings' testimony. First, the growth policy process was endorsed enthusiastically as were the consensus policies enunciated in the City and Town Center Report. Second, the need for continuing followthrough was emphasized.

Twenty of the thirty-six Report recommendations have been implemented in seventeen legislative enactments and through various administrative actions. Additional bills are pending before the Great and General Court. The success of the growth policy development process in Massachusetts is attributable largely to the level and quality of the Local Growth Policy Committees' work. The legislature could not ignore proposals that emerged from such a broad-based "grass roots" effort.

53. Mass. H. 6149 (June 29, 1978) (1978 Regular Session of the Massachusetts House). 